\title{
Hydrocarbon Signatures of Egg Maternity, Caste Membership and Reproductive Status in the Common Wasp
}

\author{
W. Bonckaert • F. P. Drijfhout • P. d'Ettorre • J. Billen • \\ T. Wenseleers
}

Received: 10 August 2011 /Revised: 7 November 2011 / Accepted: 27 December 2011

(C) Springer Science+Business Media, LLC 2012

\begin{abstract}
In most ants, bees, and wasps, the workers are capable of challenging the reproductive monopoly of the queen by laying unfertilized, male eggs. An important mechanism that can resolve this conflict is policing, whereby the queen or workers prevent successful worker reproduction by selectively eating worker-laid eggs or by attacking egglaying workers. Egg policing by workers has been shown
\end{abstract}

Electronic supplementary material The online version of this article (doi:10.1007/s10886-011-0055-9) contains supplementary material, which is available to authorized users.

W. Bonckaert $(\bowtie) \cdot J$. Billen $\cdot$ T. Wenseleers

Laboratory of Entomology, Zoological Institute,

Department of Biology, Catholic University of Leuven,

Naamsestraat 59,

3000 Leuven, Belgium

e-mail: wim.bonckaert@gmail.com

F. P. Drijfhout

Chemical Ecology Group, School of Physical and Geographical

Sciences, Lennard-Jones Laboratory, Keele University,

Keele ST5 5BG, UK

P. d'Ettorre

Centre for Social Evolution, Department of Biology,

University of Copenhagen,

Universitetsparken 15 ,

2100 Copenhagen, Denmark

P. d'Ettorre

Laboratoire d'Ethologie Expérimentale et Comparée,

Université Paris 13,

Villetaneuse, France

Present Address:

W. Bonckaert

Laboratoire d'Ethologie et de Cognitions Comparées,

Université Paris Ouest Nanterre La Défense,

200 Avenue de la République,

92001 Nanterre Cedex, France to occur in several social wasp species, but the information used by worker wasps to discriminate between queen-laid and worker-laid eggs has never been investigated. Our aim, therefore, was to investigate if hydrocarbons might be used in egg policing by workers in the common wasp, Vespula vulgaris, where worker policing previously has been shown to be effective. Our results show that 51 different hydrocarbons are present on the surface of newly-laid eggs, and that there are pronounced quantitative differences in the hydrocarbon profiles of queen-laid and worker-laid eggs, with longer-chained alkenes and methylated alkanes $\left(\mathrm{C}_{28}-\mathrm{C}_{31}\right)$ in particular being more abundant on the surface of queen-laid eggs. We further show that the hydrocarbon profiles on the surface of queen-laid and worker-laid eggs resemble those found on the mother queen's and workers' cuticles. Interestingly, longer-chained methylated alkanes also were more abundant on the cuticle of both mother queens and reproductive workers, suggesting that these compounds are linked to fertility, as has also been found to be the case in several ant species.

Key Words Hydrocarbons · Reproductive conflict - Worker policing $\cdot$ Social insects $\cdot$ Vespinae $\cdot$ Vespula vulgaris

\section{Introduction}

Insect societies are among the most highly complex and well-organized societies known in the animal kingdom, to the extent that they are often referred to as "super-organisms" (Hölldobler and Wilson, 2009; Queller and Strassmann, 2009; Strassmann and Queller, 2010). This high level of integration is surprising, given the fact that social insect colonies are typically families, and not genetically identical clones and that, under such circumstances, social conflicts among colony members might be expected to be rife. Over the last decades, 
however, it has been established that one of the main reasons for some of these conflicts to be less apparent than expected is the presence of various evolved mechanisms that reduce conflict (reviewed in Ratnieks et al., 2006; Ratnieks and Wenseleers, 2008). In most ants, bees and wasps, for example, the workers are capable of challenging the reproductive monopoly of the queen by laying unfertilized, male eggs. However, an important mechanism that can resolve this conflict is policing, which is the phenomenon whereby the queen or workers prevent successful worker reproduction by selectively eating worker-laid eggs or by attacking egg-laying workers (reviewed in Wenseleers and Ratnieks, 2006).

At a proximate level, the fact that the queen or workers are capable of discriminating eggs laid by queens from those laid by workers, and between laying and non-laying workers, implies the presence of accurate recognition mechanisms. Most researchers believe that these are based on the detection of differences in the surface chemistry of queen- and workerlaid eggs, and differences in the chemical profiles of laying and non-laying workers (reviewed in Monnin, 2006; Le Conte and Hefetz, 2008; Liebig, 2010). Worker policing by egg eating was first discovered in the Western honeybee (Ratnieks and Visscher, 1989), and since then, extensive studies on egg surface chemistry of queen-laid and workerlaid eggs in honeybees have been conducted (reviewed in Le Conte and Hefetz, 2008; Liebig, 2010). Nevertheless, it remains unclear exactly how honeybee workers discriminate between queen-laid and worker-laid eggs. Thus far, it has been established that differences in surface hydrocarbon profiles do not seem to play a role (Martin et al., 2004). Instead, discrimination is probably based on the presence of certain esters derived from the Dufour's gland, since queens produce higher levels of esters in their Dufour's gland than laying workers (Katzav-Gozansky et al., 1997). Treatment of worker-laid eggs with Dufour's gland extracts reduced policing rates (Ratnieks, 1995). Nevertheless, experiments to directly show the function of the esters in egg discrimination in the honeybees have failed; artificial applications of queenlike esters either did not protect the worker-laid eggs at all (Katzav-Gozansky et al., 2001) or only delayed egg-eating (Martin et al., 2002).

Aside from honeybees, attempts have been made to identify pheromones used in worker policing in several ant species (reviewed in Monnin, 2006; Le Conte and Hefetz, 2008; Liebig, 2010). In Pachycondyla inversa, early results based on gas chromatography (GC) and electroantennography showed that the hydrocarbon, 3,11-dimethylheptacosane, was more abundant on the surface of queen-laid eggs, and that this compound triggered a specific response in the antennae of workers (D'Ettorre et al., 2004b), suggesting that it was used as a discrimination pheromone enabling selective policing of worker-laid eggs (D'Ettorre et al., 2004a). Nevertheless, later bioassays have been unable to prove this assertion when field colonies were used (van Zweden et al., 2009). In the ant Camponotus floridanus, queen- and worker-laid eggs exhibit cuticular hydrocarbon profiles that resemble those of the mother queens and workers, respectively, and when hydrocarbons from the queen's cuticle were transferred onto worker-laid eggs they were policed at a reduced rate (Endler et al., 2004). In addition to chemical differences between queen- and worker-laid eggs, Meunier et al. (2011) showed that the social origin of queen-laid eggs can influence their acceptance by foreign workers. The most direct proof of the involvement of a cuticular hydrocarbon in worker policing is in the ant Aphaenogaster cockerelli. In this species, workers that activate their ovaries have more $n$-pentacosane on their cuticle, and the transfer of this compound onto the cuticle of non-reproductive workers induced biting by workers in queenright colonies (Smith et al., 2009). Thus, pentacosane is an indicator of fertility and is most likely used by workers to identify and police nestmates that activate their ovaries. Consistent quantitative differences in cuticular hydrocarbon profiles of laying and non-laying workers also occur in several other ant species (reviewed in Monnin, 2006; Le Conte and Hefetz, 2008; Liebig, 2010), but their use in worker policing has not been demonstrated.

The aim of the present study was to investigate if hydrocarbons might be used in egg policing by workers in the common wasp, Vespula vulgaris (Vespinae), where worker policing has evolved independently from ants and bees (Foster and Ratnieks, 2001). Because workers in this species selectively eat worker-laid eggs (Foster and Ratnieks, 2001), our study aimed at quantifying the differences in the surface hydrocarbon profiles of queen- and worker-laid eggs by using GC-mass spectrometric (MS) analysis. In addition, we tested whether egg profiles are closest to either cuticular or Dufour's gland profiles of reproductive individuals, thereby enabling determination of the possible exocrine source of the hydrocarbons used in egg policing. In addition, we investigated whether cuticular hydrocarbons provide information on caste membership, colony membership, and the reproductive status of queens and workers.

\section{Methods and Materials}

Colony Collection In August and September 2007, five mature colonies of $V$. vulgaris were collected in the vicinity of Leuven, Belgium. Nests were found underground or in attics and contained ca. 400-600 workers, and a single reproductive mother queen. After collection, the nests were transferred to $30 \mathrm{~cm}$ (wide) $\times 32 \mathrm{~cm}$ (deep) $\times 40 \mathrm{~cm}$ (high) wooden observation boxes with a $5 \mathrm{~cm}$ diameter entrance hole, which allowed the workers to forage naturally. The colonies were used to collect queen- and worker-laid eggs 
( $N=44$ and $N=39$, respectively), workers $(N=101)$, virgin and reproductive queens ( $N=17$ and $N=4$, respectively). Seven nest-searching $V$. vulgaris queens (referred to as spring-collected queens hereafter) also were collected in the surroundings of Kampenhout, Belgium, in April 2007, as well as nine reproductive queens from colonies which had been used in another experiment.

Queen-laid and Worker-laid Eggs Queen-laid eggs were collected from the five queenright nests by removing the eggs present in the lowest comb, which consists of large cells used to rear gynes and males. To allow this comb to be easily taken out and returned to the colony, the comb was first glued onto a thin iron wire attached to a piece of modeling clay, and then reinserted into the nest. After $24 \mathrm{hr}$, the comb was removed, queen-laid eggs were collected, and visually checked for damage on a glass plate. Only intact eggs were used for chemical analysis. Most or all of the eggs collected this way were queen-laid eggs since in queenright colonies of $V$. vulgaris only $1.0 \%$ of the workers have functional ovaries, and in a policing trial all 120 worker-laid eggs were removed within $16 \mathrm{hr}$ (Foster and Ratnieks, 2001). Furthermore, the rate of ovary activation of $V$. vulgaris workers in queenright colonies does not differ significantly between Belgian and British populations (A. Van Oystaeyen and T. Wenseleers, unpublished results). Subsequently, the colonies were orphaned, and the reproductive mother queens were frozen at $-20^{\circ} \mathrm{C}$ (except for one colony from which the mother queen could not be retrieved). Approximately 2 weeks after being orphaned, workers started laying eggs, and these eggs were collected in the same way as queen-laid eggs.

Surface hydrocarbons from queen- and worker-laid eggs were extracted by washing each individual egg in $40 \mu \mathrm{l}$ of HPLC-grade pentane (Acros Organics, Belgium) for $1 \mathrm{~min}$, of which the first and last $15 \mathrm{sec}$ involved gentle mixing. The solvent then was allowed to evaporate at room temperature in a laminar flow hood. Each extract was resuspended in $10 \mu \mathrm{l}$ pentane, of which $2 \mu \mathrm{l}$ were injected splitless in an Agilent 6850 GC (Agilent Technologies, USA), equipped with an HP-1 capillary column $(30 \mathrm{~m} \times 320 \mu \mathrm{m} \times 0.25 \mu \mathrm{m})$, a split-splitless injector, a flame ionization detector (FID), and a helium carrier gas flow of $1.1 \mathrm{ml} / \mathrm{min}$. After an initial hold of $1 \mathrm{~min}$ at $70^{\circ} \mathrm{C}$, the temperature was raised to $150^{\circ} \mathrm{C}$ at $20^{\circ} \mathrm{C} / \mathrm{min}$, then to $320^{\circ} \mathrm{C}$ at $3.5^{\circ} \mathrm{C} / \mathrm{min}$, with a final hold at $320^{\circ} \mathrm{C}$ for $5 \mathrm{~min}$.

Cuticular and Dufour's Gland Hydrocarbons After having collected worker-laid eggs, all workers inside the nests, as well as virgin queens from two colonies, were killed by freezing at $-20^{\circ} \mathrm{C}$. Wasps were dissected to measure ovary development and to obtain the Dufour's gland. Workers were classified in three categories based on the size of the biggest oocyt being smaller than $25 \%, 25-50 \%$, and greater than $50 \%$ the size of a freshly laid egg, respectively: those with undeveloped ovaries (UND, $N=49$ ), partially developed ovaries (PD, $N=8$ ), or fully developed ovaries (FD, $N=44$ ). The cuticular hydrocarbons of adult wasps were extracted by immersing head and thorax for $10 \mathrm{~min}$, of which the first and the last $15 \mathrm{sec}$ involved gentle mixing in $600 \mu \mathrm{l}$ or $1 \mathrm{ml}$ of pentane for adult workers and queens, respectively. We used only the head and thorax since the abdomen was used to obtain the Dufour's gland. Solvent then was allowed to evaporate at room temperature in a laminar flow hood. Each extract was resuspended in $50 \mu \mathrm{l}$ of pentane for workers and $100 \mu \mathrm{l}$ pentane for queens, of which $2 \mu \mathrm{l}$ were analyzed by GC in the splitless mode. The Dufour's gland was dissected and placed into a micro-insert to which $100 \mu$ l of pentane were added, and the contents were crushed with forceps and vortexed for $10 \mathrm{sec}$. Solvents were evaporated as above, and each extract was resuspended in 10,100 , and $200 \mu \mathrm{l}$ of pentane for workers and reproductive queens, virgin queens and spring-collected queens, respectively, of which $2 \mu \mathrm{l}$ were analyzed by GC as above. Different amounts of pentane were necessary to obtain comparable chromatograms (total concentration of compounds) for the different classes of queens.

Identification of Compounds Compound identities were determined on the basis of their mass spectra from GC-MS analysis performed using an Agilent 7890A GC, equipped with a ZB-5HT capillary column $(30 \mathrm{~m} \times 320 \mu \mathrm{m} \times 25 \mu \mathrm{m})$ coupled to a $5975 \mathrm{C}$ Inert XL EI/CI MSD with electron ionization $(70 \mathrm{eV})$, and a helium carrier gas flow of $1.5 \mathrm{ml} / \mathrm{min}$, using the same temperature program as above, and by subsequently comparing diagnostic ions of the mass spectra with published data (e.g., Bonavita-Cougourdan et al., 1987; Howard et al., 2001).

Analysis of Hydrocarbon Profiles Peak areas of 51 identified hydrocarbons (or mixtures of several co-eluting hydrocarbons) found on the surface of queen- and worker-laid eggs, and the cuticle of workers and queens (Fig. 1, Table S1), as well as those found in the Dufour's gland of workers (UND, $N=23$; PD, $N=3$; FD, $N=28$ ) and queens (reproductive queens $\mathrm{Q}, N=13$; spring-collected queens, $\mathrm{SQ}, N=7$; virgin queens, $\mathrm{VQ}, N=17)$ were quantified using the software Agilent ChemStation (Rev. A.09.01, Agilent Technologies) normalized to relative concentrations with a Ztransformation (Aitchison, 1986). These normalized concentrations then were used as variables in a principal component analysis (PCA), after which the scores for all principal components with an eigenvalue greater than 1 were used as independent variables in further discriminant analyses to determine if variation in hydrocarbons allowed us to differentiate among worker- and queen-laid eggs, as 
well as among workers from different colonies, and to determine if hydrocarbon profiles contained information regarding caste and fertility. We divided the hydrocarbons into two groups (shorter-chained and longer-chained) based on their loadings on the PC explaining the most variation. Differences in the total relative abundances of these particular classes of compounds (i.e., shorter-chained and longerchained alkanes, alkenes, and methylated alkanes) were tested using independent $t$-tests. Lastly, the mean City-block (Manhattan) distances between the surface hydrocarbon profiles of queen-laid eggs and the cuticular and Dufour's gland compounds of reproductive queens on the one hand, and between worker-laid eggs and the cuticular and Dufour's gland hydrocarbon profiles of reproductive workers on the other hand, were calculated. These values were used in Wilcoxon matched pairs tests to determine if the surface hydrocarbon profiles of eggs were closer to the cuticular than to the Dufour's gland hydrocarbon profiles.

To investigate in more detail which compounds could be used to identify colony identity, we preformed a separate principal component analysis using only the cuticular hydrocarbon profiles of workers with undeveloped ovaries, after which the scores for all principal components with an eigenvalue greater than 1 were used as independent variables in a discriminant analysis. We used this approach because colony membership information might be masked by fertility, and because recognizing sterile workers returning from foraging is essential in the context of nestmate recognition. The program STATISTICA 9.1 (StatSoft Inc., USA) was used for all statistical analyses.

\section{Results}

Identity of Compounds A total of 51 hydrocarbons were identified from the surface of queen-laid and worker-laid eggs, and on the cuticle and in the Dufour's gland of queens and workers. The hydrocarbon profiles consisted of linear alkanes and alkenes, and branched alkanes with a chain length ranging from $\mathrm{C}_{23}$ to $\mathrm{C}_{31}$ (Fig. 1, Table S1). A PCA analysis produced six principal components with eigenvalues higher than 1 , which together explained $84.6 \%$ of the variance in the data (Table S2). Based on the loadings of the hydrocarbons on the PC explaining the most variation (PC 1) we could divide the hydrocarbons into two groups, shorterchained $\left(\mathrm{C}_{23}-\mathrm{C}_{27}\right)$ and longer-chained $\left(\mathrm{C}_{28}-\mathrm{C}_{31}\right)$ hydrocarbons.

Egg Maternity PCA analysis shows that the surface hydrocarbons of worker-laid eggs were significantly different from those of queen-laid eggs, and that it was possible to correctly assign $89.2 \%$ of all eggs to the right egg-type (Table S3; Wilks' $\lambda=0.53, F_{6,76}=7.89, P<0.001$ ), with three PCs being significant for the discrimination according to egg-type (PC 1, Partial Wilks' $\lambda=0.80, P<0.001$; PC 2, Partial Wilks' $\lambda=0.91, P=0.006$; PC 5, Partial Wilks' $\lambda=$ $0.93, P=0.02$; Fig. 2). Furthermore, all the variation could be explained by a single significant discriminant function (canonical correlation $=0.72 ;$ Wilks' $\lambda=0.48, \chi 2=57.55, d f=$ $6, P<0.001)$, which was determined principally by PC 1 (standardized coefficient -0.76 , correlation -0.65 ), and hence by the compounds 3-, 5-, 7-, 9-, 11- $\mathrm{MeC}_{23}, 5, \mathrm{x}-$ $\operatorname{diMeC}_{23}, 3, \mathrm{x}$-diMeC $23,10-, 12-, 14-\mathrm{MeC}_{24}, 6-\mathrm{MeC}_{24}, 4-$ $\mathrm{MeC}_{24}, 11-$, 13-, 15- $\mathrm{MeC}_{25}, 5, \mathrm{x}$-diMeC $25,3, \mathrm{x}$-diMeC 25 , and $3-\mathrm{MeC}_{29}$ (absolute value of factor loadings $>0.9$, Table S2). Univariate tests on the total relative abundance of particular classes of compounds (Table S1) show that queen-laid eggs had a higher proportion of longer-chained alkenes and methylated alkanes $\left(\mathrm{C}_{28}-\mathrm{C}_{31}\right)$ as well as shorter-chained $n$-alkanes $\left(\mathrm{C}_{23}-\mathrm{C}_{27}\right)$ on the surface (three independent $t$-test, $\mathrm{t}_{93}=5.24, P<0.001 ; t_{93}=3.67, P<0.001$; $\mathrm{t}_{93}=4.03, P<0.001$, respectively), while shorter-chained methylated alkanes $\left(\mathrm{C}_{23}-\mathrm{C}_{27}\right)$ were more abundant on worker-laid eggs (independent $t$-test, $t_{93}=-5.14, P<0.001$ ). The relative abundance of shorter-chained alkenes $\left(\mathrm{C}_{23}-\mathrm{C}_{27}\right)$ and longer-chained $n$-alkanes $\left(\mathrm{C}_{28}-\mathrm{C}_{31}\right)$, however, did not differ between the two types of eggs (two independent $t$-test, $t_{93}=0.50, P=0.61 ; t_{93}=-1.17, P=0.24$, respectively).

The surface hydrocarbon profiles of queen-laid eggs were closer to the cuticular hydrocarbon profiles of queens than to the queen's Dufour's gland hydrocarbon profiles, as measured by the average City-block (Manhattan) distances (Wilcoxon matched pairs test, $P<0.001)$. The same was true for worker-laid eggs i.e., the hydrocarbon profile of a workerlaid egg resembled the cuticular hydrocarbon profile of a reproductive worker more than the Dufour's gland hydrocarbon profile of a reproductive worker (Wilcoxon matched pairs test, $P<0.001)$.

Caste Membership and Fertility Reproductive queens, spring-collected queens, virgin queens, and workers with undeveloped, partially developed, or fully developed ovaries could be discriminated based on their cuticular hydrocarbon profile (Wilks' $\lambda=0.0059, F_{30,510}=44.47, P<0.001$ ). Of all individuals, $81.2 \%$ were assigned correctly, and the majority of misclassifications occurred between workers with partially and fully developed ovaries (Table S4). When workers with partially developed ovaries were excluded from the analysis, $83.8 \%$ of all individuals were correctly classified (Table S4; Wilks' $\lambda=0.0053, F_{24,419}=61.27, P<$ 0.001 ) with all PCs being significant but PC 1 and PC 5 having the lowest partial Wilks' $\lambda$ (PC 1, Partial Wilks' $\lambda=$ 0.15 ; PC 5, Partial Wilks' $\lambda=0.26$; other PCs Partial Wilks' $\lambda>0.64)$. Furthermore, all variation could be explained by four significant discriminant functions (function 1 explaining $61.3 \%$, canonical correlation $=0.95$; Wilks' $\lambda=0.0053$, $\chi^{2}=648.2, d f=24, P<0.001$; function 2 explaining 
$\mathbf{a}$

\begin{tabular}{|c|c|c|c|}
\hline Peak\# & Identification & Peak\# & Identification \\
\hline $\begin{array}{c}1 \\
2 \\
3 \\
4 \\
5 \\
6 \\
7 \\
8 \\
9 \\
10 \\
11 \\
12 \\
13\end{array}$ & 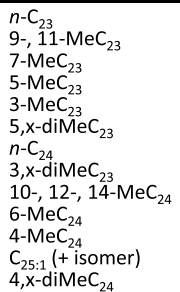 & $\begin{array}{l}14 \\
15 \\
16 \\
17 \\
18 \\
19 \\
20 \\
21 \\
22 \\
23 \\
24 \\
25 \\
26\end{array}$ & 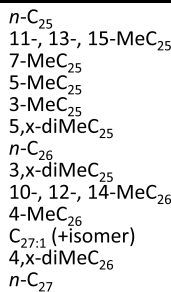 \\
\hline
\end{tabular}

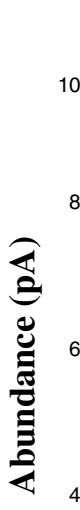

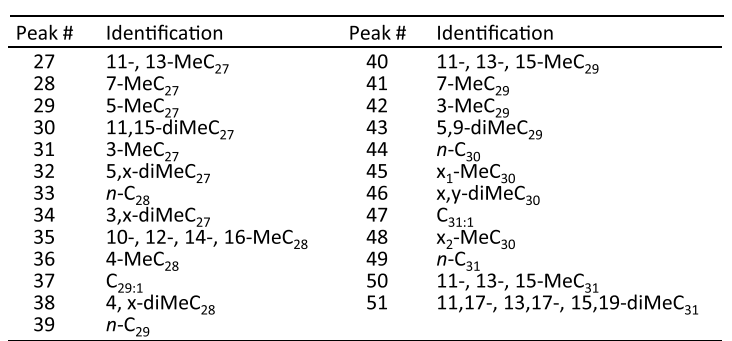

$39 \quad n-C_{29}$

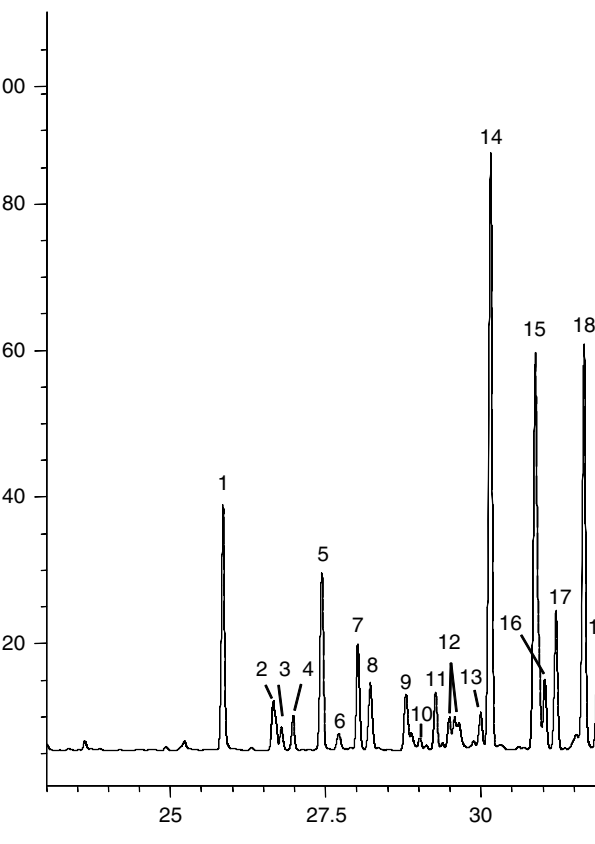

Retention time (min)

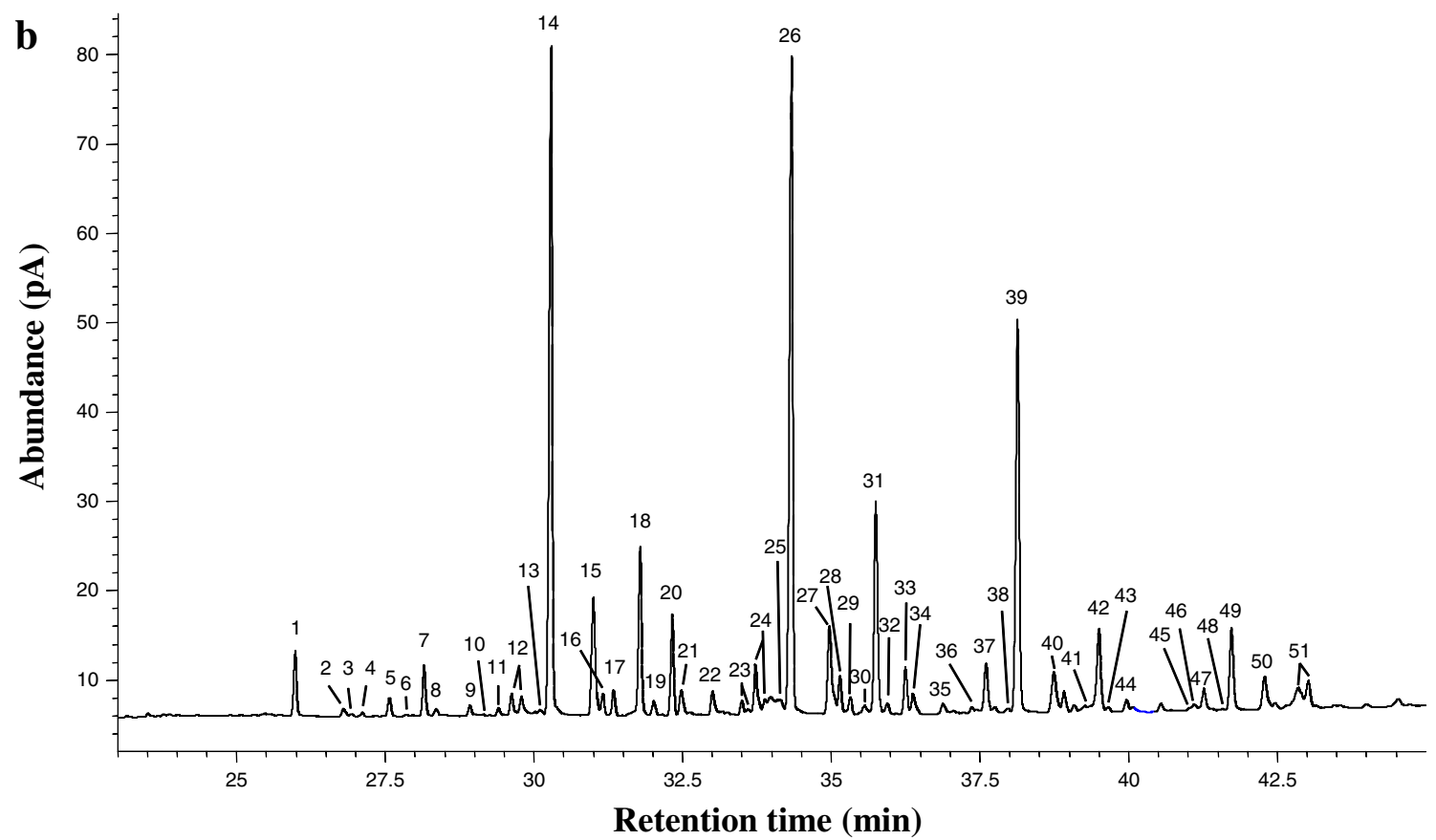

Fig. 1 Typical gas chromatogram of the surface hydrocarbon profile of a Vespula vulgaris worker-laid egg and $\mathbf{b}$ a $V$. vulgaris queen-laid egg. The identity of the peaks, as established by GC-MS analysis, is given in the inset table. For dimethyl alkanes, $\mathrm{x}$ represents the position of the second methyl group (see Table S1) 


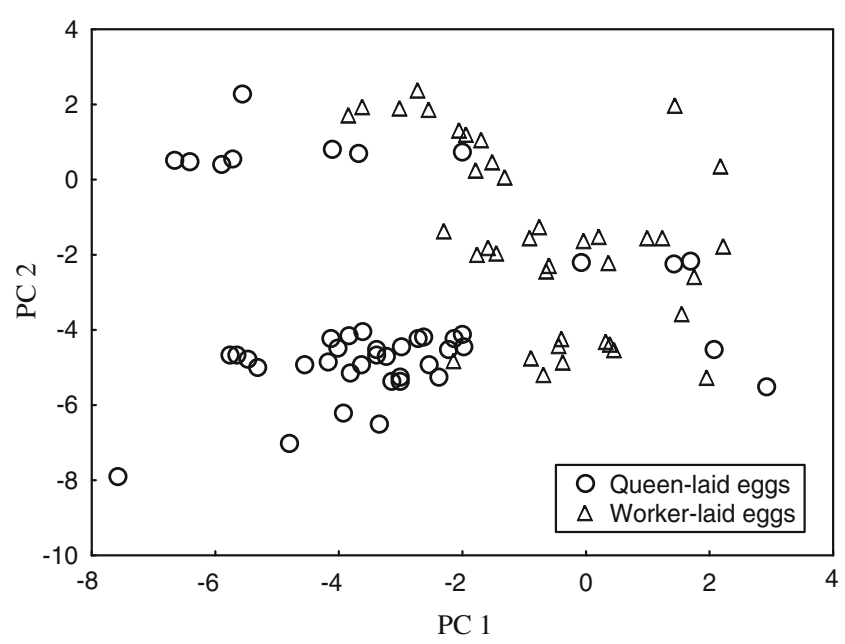

Fig. 2 Plot of the first two principal components showing the chemical difference between queen-laid and worker-laid eggs

$26.0 \%$, canonical correlation $=0.90$; Wilks' $\lambda=0.058, \chi 2=$ 352.4, $d f=15, P<0.001$; function 3 explaining $11.9 \%$, canonical correlation $=0.81$; Wilks' $\lambda=0.30, \chi^{2}=147.7$, $d f=8, P<0.001$; function 4 explaining $0.8 \%$, canonical correlation $=0.34 ;$ Wilks' $\lambda=0.89, \chi^{2}=14.89, d f=3, P=$ 0.002). The first discrimination function separated the queens from the workers, the second separated the different classes of queens, the third separated the reproductive queen from virgin and spring-collected queens, and the fourth moderately separated the workers with fully developed and undeveloped ovaries (Fig. 3).

As for egg maternity, the discrimination function separating the cuticular profiles of queens and workers (Fig. 3a) was determined mostly by PC 1 (standardized coefficient -1.20 , correlation -0.79 ), and hence by the compounds $3-$, 5-, 7-, 9-, 11- $\mathrm{MeC}_{23}, 5, \mathrm{x}-\mathrm{diMeC}_{23}, 3, \mathrm{x}-\mathrm{diMeC}_{23}, 10-, 12-$ ,14- $\mathrm{MeC}_{24}, 6-\mathrm{MeC}_{24}, 4-\mathrm{MeC}_{24}, 11-, 13-, 15-\mathrm{MeC}_{25}, 5$,x$\mathrm{diMeC}_{25}, 3$, $\mathrm{x}-\mathrm{diMeC}_{25}$, and $3-\mathrm{MeC}_{29}$ (absolute value of factor loadings $>0.9$, Table S2). As with the egg discrimination results, univariate tests showed that the cuticle of reproductive queens contained more longer-chained $n$-alkanes, alkenes, and methylated alkanes $\left(\mathrm{C}_{28}-\mathrm{C}_{31}\right)$, as well as shorter-chained $n$-alkanes $\left(\mathrm{C}_{23}-\mathrm{C}_{27}\right)$ (four independent $t$ tests, $t_{55}=17.97, P<0.001 ; t_{55}=2.04, P=0.046 ; t_{55}=2.96$, $P=0.005 ; t_{55}=15.37, P<0.001$, respectively), while the cuticle of reproductive workers contained a higher proportion of shorter-chained alkenes and methylated alkanes $\left(\mathrm{C}_{23}-\mathrm{C}_{27}\right)$ (two independent $t$-test, $t_{55}=-7.33, P<0.001$; $\left.t_{55}=-18.80, P<0.001\right)$. The discrimination function separating the three classes of queens (Fig. 3a) was determined primarily by PC 5 (standardized coefficient -1.00 , correlation -0.97), with $4, \mathrm{x}$-diMeC 28 being the compound with the highest factor loading on PC 5 (absolute value of factor loading $>0.5$, Table $\mathrm{S} 2$ ). The discrimination function separating the reproductive queen from virgin and spring- collected queens (Fig. 3b) was determined mainly by PC 3 (standardized coefficient -0.85 , correlation -0.54 ), and hence by the compounds $10-, 12-, 14-\mathrm{MeC}_{26}, 11-, 13-$ $\mathrm{MeC}_{27}, 5, \mathrm{x}-\mathrm{diMeC}_{27}, 10-, 12-, 14-, 16-\mathrm{MeC}_{28}, 4, \mathrm{x}-$ $\mathrm{diMeC}_{28}$, and 5,9-diMeC 29 (absolute value of factor loadings $>0.5$, Table $\mathrm{S} 2$ ). The discrimination function separating workers with fully developed ovaries from workers with undeveloped ovaries (Fig. 3c), was determined principally by PC 4 (standardized coefficient 0.63 , correlation 0.95 ), and hence by the compounds $\mathrm{C}_{25: 1}, \mathrm{x}_{1}-\mathrm{MeC}_{30}$ and $\mathrm{x}, \mathrm{y}-$ $\operatorname{diMeC}_{30}$ (absolute value of factor loadings $>0.5$, Table S2).

Since the hydrocarbons found in the Dufour's gland were qualitatively identical to the ones found on the cuticle, and since previous studies have shown the importance of Dufour's gland hydrocarbons in signaling fertility in the paper wasp Ropalidia marginata (Mitra and Gadagkar, 2011; Mitra et al., 2011), the previous discriminant analysis (excluding workers with partially developed ovaries) could also be performed using the Dufour's gland hydrocarbons. However, the accuracy of the classification using cuticular hydrocarbon profiles was significantly better (Wilcoxon matched pairs test on the percentages of correctly classified classes of individuals, one-sided $P=0.04$ ).

Colony Membership Cuticular hydrocarbon profiles of workers from the five colonies studied were significantly different, and it was possible to correctly assign $64.4 \%$ of all individuals to their colony of origin (Table S5; Wilks' $\lambda=$ $0.23, \mathrm{~F}_{24,318}=7.01, P<0.001$ ), with three $\mathrm{PCs}$ being significant for the discrimination (PC 1, Wilks' $\lambda=0.45$, Partial Wilks' $\lambda=0.50, F_{4,91}=22.41, P<0.001$; PC 3, Wilks' $\lambda=$ 0.26 , Partial Wilks' $\lambda=0.89, F_{4,91}=2.86, P=0.03$; PC 5, Wilks' $\lambda=0.28$, Partial Wilks' $\lambda=0.83, F_{4,91}=4.74, P=$ 0.002). Two functions, explaining $94 \%$ of the variation, were significant (function 1 explaining $82 \%$, canonical correlation $=0.81 ;$ Wilks' $^{\prime} \lambda=0.23, \chi 2=139.68, d f=24, P<$ 0.001 ; function 2 explaining $12 \%$, canonical correlation= 0.47 ; Wilks' $\lambda=0.68, \chi 2=36.70, d f=15, P=0.001$ ) with PC 1 and PC 3 having the most weight on the first and second discrimination functions, respectively (PC 1, standardized coefficient -1.09 , correlation -0.54 ; PC 3 , standardized coefficient -0.43 , correlation -0.73 ).

When the analysis of cuticular hydrocarbon profiles was restricted to that of undeveloped workers, a PCA analysis produced seven principal components with eigenvalues higher than 1 , which together explained $92.1 \%$ of the variance in the data (Table S6). In a subsequent discriminant analysis, it was possible to correctly assign $85.7 \%$ of all individuals to their colony of origin (Table S7; Wilks' $\lambda=$ $0.017, \mathrm{~F}_{28,138}=10.31, P<0.001$ ), with all PCs but one (PC 6) being significant. All variation could be explained by four significant functions of which the first two functions explained $87 \%$ of the variation (function 1 explained $62 \%$, 
Fig. 3 Discriminant analysis based on the relative proportions of 51 cuticular hydrocarbons from reproductive queens (Q), spring-collected queens (SQ), virgin queens (VQ), workers with fully developed ovaries (FD), and workers with undeveloped ovaries (UND). The percentage of variance explained by function 1 and 2 (a), function 1 and 3 (b), function 1 and 4 (c) is given in parentheses

canonical correlation $=0.93$; Wilks' $\lambda=0.017, \chi^{2}=170.64$, $d f=28, P<0.001$; function 2 explained $25 \%$, canonical correlation $=0.84 ;$ Wilks $^{\prime} \lambda=0.12, \chi 2=89.30, d f=18$, $P<.001)$. The first and second discrimination function were determined chiefly by PC 2 (standardized coefficient -1.32 , correlation -0.31) and PC 1 (standardized coefficient 0.88 , correlation 0.63), respectively. Furthermore, PC 2 and PC 1 were mostly determined by shorter-chained and longerchained hydrocarbons, respectively. This means that practically all hydrocarbons are needed to correctly classify the workers according to their colony of origin. Since the hydrocarbons found in the Dufour's gland were qualitatively identical to the ones found on the cuticle, and since previous studies on paper wasps have shown that individuals can be correctly classified according to their colony of origin based on Dufour's gland hydrocarbons (Dani et al., 1996; Mitra et al., 2011), the previous discrimination analysis could also be done using the Dufour's gland hydrocarbon profiles of workers with undeveloped ovaries. This led to a correct classification of $90.5 \%$ of all individuals to their colony of origin (Wilks' $\lambda=0.069, F_{21,32}=2.35, P<0.014$ ), which was not significantly different from the correct assignment rate based on the cuticular hydrocarbon profiles, $85.7 \%$ (Wilcoxon matched pairs test on the percentages of correctly classified classes of individuals, two-sided $P=0.42$ ). However, only one function, explaining $54.7 \%$ of the variation, was actually significant (canonical correlation $=0.85$; Wilks $\left.\lambda=0.069, \chi^{2}=38.76, d f=21, P=0.01\right)$.

\section{Discussion}

Our results show that queen-laid and worker-laid eggs can be discriminated based on their surface hydrocarbon profiles, with longer-chained alkenes and methylated alkanes $\left(\mathrm{C}_{28}-\mathrm{C}_{31}\right)$ being more abundant on the surface of queen-laid eggs. This means that the hydrocarbons on the surface of queen- and worker-laid eggs, in principle, contain all the necessary information for workers to effectively recognize and police worker-laid eggs. Moreover, the hydrocarbon profiles on the surface of queen- and worker-laid eggs resemble those on queens' and workers' cuticles, respectively. This is in concordance with previous results found in other social Hymenoptera (reviewed in Monnin, 2006; Le Conte and Hefetz, 2008; Liebig, 2010), which suggests that the hydrocarbons on the cuticle and on the egg surface have the same exocrine source. In insects, cuticular hydrocarbons
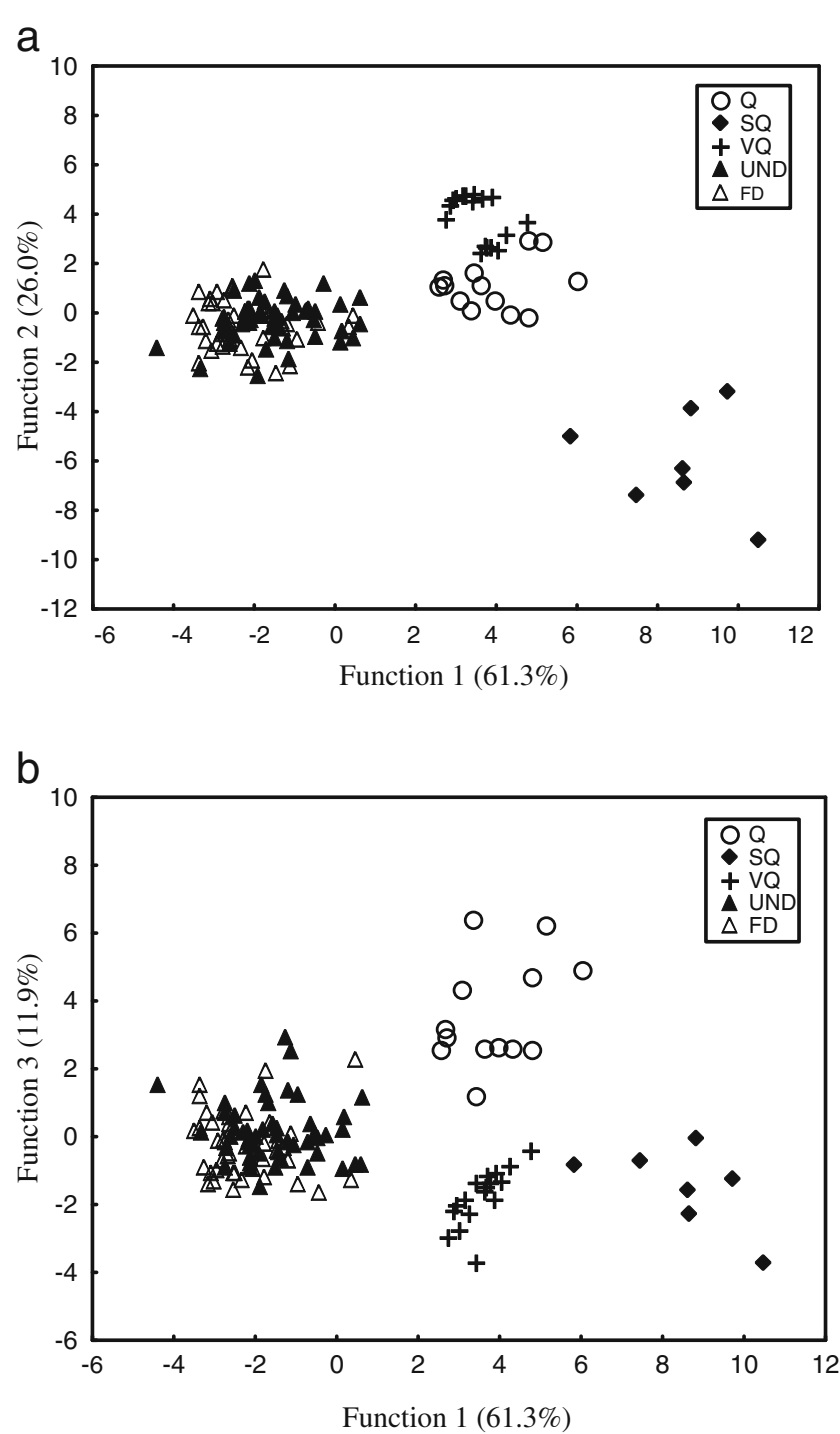

C

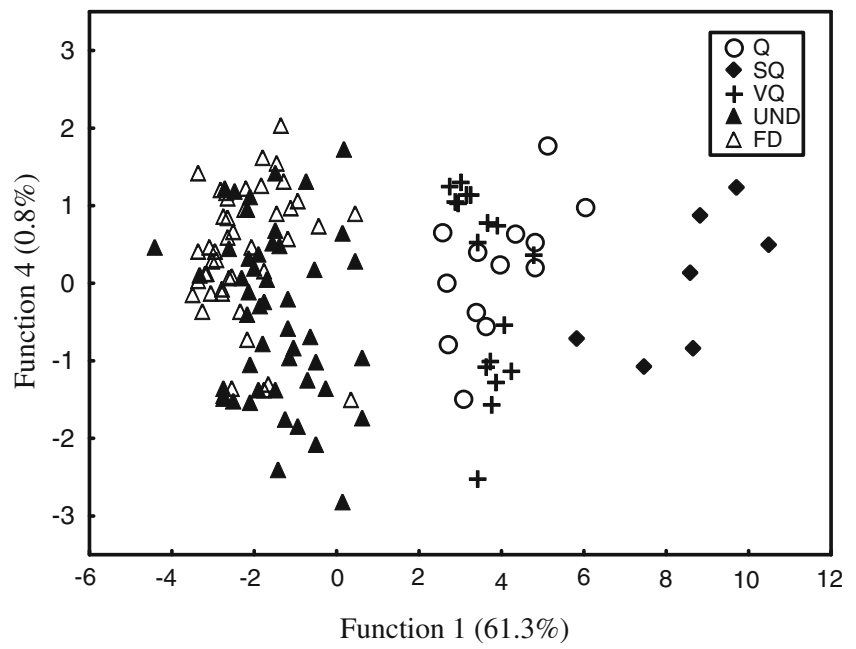

are produced in oenocytes associated with epidermal tissue or are present in the peripheral fat body, and are transported 
for deposition on the cuticle by lipophorin (reviewed in Bagnères and Blomquist, 2010). In addition, in the German cockroach Blattella germanica and the house fly Musca domestica, it has been shown that lipophorin transports hydrocarbons to the ovaries (Schal et al., 2001; Fan et al., 2002). Despite the fact that this pathway has never been confirmed for social Hymenoptera, several studies provide indirect evidence that hydrocarbons on the surface of eggs originate from the same source as cuticular hydrocarbons (Monnin and Peeters, 1997; D’Ettorre et al., 2004a; Endler et al., 2004, 2006; Dapporto et al., 2007; Lommelen et al., 2008). Nevertheless, it should be noted that in this study all hydrocarbons found on the surface of the eggs were also found in the wasps' Dufour's glands, so it is possible that this gland also contributes to the hydrocarbon composition found on the surface of the eggs. Indeed, in contrast to the situation in ants, the posterior part of the Dufour's gland duct in wasps opens in the dorsal vaginal wall, making it potentially suitable for egg marking (Billen, 1987, 2006). In addition, Dani et al. (1996) demonstrated that in the paper wasp, Polistes dominulus, Dufour's gland of foundresses contained the same hydrocarbons as those found on the cuticle, perhaps as a result of the spreading of the secretion of the Dufour's gland over the body surface during selfgrooming. Therefore, our results suggest that in Vespula vulgaris both the oenocytes and Dufour's gland might contribute to the formation of the specific hydrocarbon profiles present on the surface of the eggs and cuticle.

In addition to our data that suggested that hydrocarbons on the cuticle and on the egg surface have the same exocrine source, specific longer-chained methylated alkanes $\left(\mathrm{C}_{28}-\mathrm{C}_{31}\right)$ were more abundant on the cuticle of queens relative to workers, as well as on reproductive workers relative to nonreproductive workers. This suggests that these compounds are linked to fertility, as has been found in several ant species (reviewed in Monnin, 2006; Le Conte and Hefetz, 2008; Liebig, 2010). For example, methylated alkanes $\mathrm{C}_{27} \mathrm{C}_{34}$ were significantly more abundant on the cuticle of Linepithema humile reproductive queens compared to the cuticle of virgin queens (de Biseau et al., 2004), and in Lasius niger specific long-chained hydrocarbons $\left(3-\mathrm{MeC}_{31}, \mathrm{C}_{31: 1}\right.$, and $\left.3-\mathrm{MeC}_{29}\right)$ were related to productivity and maturation in queens, and 3$\mathrm{MeC}_{31}$ was identified as a sterility-regulating ant queen pheromone (Holman et al., 2010a,b). As with the queen pheromone in L. niger, the surface of queen-laid eggs and cuticle of $V$. vulgaris queens have a higher proportion of a similar compound $\left(3-\mathrm{MeC}_{29}\right)$ than do worker-laid eggs and the cuticle of workers. Therefore, it would be interesting to test if 3$\mathrm{MeC}_{29}$ is used as a queen pheromone in $V$. vulgaris. However, it is clear that longer-chained methylated alkanes are not always linked to fertility in social insects, and that these compounds acquired a fertility signaling role independently several times in eusocial Hymenoptera. For example, in the bald-face hornet, Dolichovespula maculata, reproductive queens did not differ in their longer-chained methylated alkanes from workers (Butts et al., 1991), and in the ant Ectatomma tuberculatum, the alkane $n-\mathrm{C}_{27}$ strongly correlated with fertility (Hora et al., 2008). Nevertheless, our data adds credence to the idea that ovarian development in social insects is interwoven with the mechanism of hydrocarbon biosynthesis (e.g., Heinze et al., 2002; Smith et al., 2009). In contrast to queens, the relative abundance of $\mathrm{C}_{25: 1}, \mathrm{x}_{1}-\mathrm{MeC}_{30}$, and $\mathrm{x}, \mathrm{y}-$ $\mathrm{diMeC}_{30}$ mainly determined the discrimination between the cuticular hydrocarbon profiles of workers with developed and undeveloped ovaries. The fact that the cuticular hydrocarbon profiles of reproductive workers differ from those of nonreproductive ones, could potentially be used to police reproductive workers via aggression. To reiterate, the most direct proof of the involvement of cuticular hydrocarbons in worker policing is for the ant Aphaenogaster cockerelli (Smith et al., 2009). Despite the fact that egg eating is most likely the main form of worker policing in V. vulgaris, the fact that some worker policing is done via aggression remains plausible.

In summary, our data show that the hydrocarbons correlated with fertility can be different for different castes in the same species. This is unique from the situation in the ants Myrmecia gulosa, Aphaenogaster cockerelli, and Pachycondyla inversa, where reproductive workers resemble the profiles of reproductive queens and, hence, the same hydrocarbons convey information on fertility in both castes (Heinze et al., 2002; Dietemann et al., 2003; Smith et al., 2008). Alternately, in the paper wasp, Polistes dominulus, dominance among foundresses determine the cuticular hydrocarbon profiles more than fertility (Dapporto et al., 2007, but see Bonavita-Cougourdan et al., 1991), suggesting that in these wasps cuticular hydrocarbon profiles represent social rather than reproductive status. Our results suggest that all hydrocarbons are necessary for nestmate recognition, whereas only a subset of specific hydrocarbons are used to signal caste and fertility in $V$. vulgaris.

Although we do not know the proximate mechanism driving the observed differences in cuticular hydrocarbon profiles in V. vulgaris, endocrine factors such as juvenile hormone might be important, as juvenile hormone plays an important role in determining the division of labor and influences cuticular hydrocarbon profiles in social Hymenoptera (e.g., Huang et al., 1994; Bloch et al., 2000; Lengyel et al., 2007).

Overall, our results show for the first time in social wasps that surface hydrocarbon profiles of queen-laid eggs and worker-laid eggs contain the necessary information for workers to effectively police worker-laid eggs. Bioassays are needed to determine if workers do indeed use these hydrocarbons for worker policing. Furthermore, our results indicate that it is possible that the Dufour's gland contributes, together with the oenocytes, to the formation of characteristic hydrocarbon profiles on the egg and body surfaces of vespines. 
Acknowledgments We thank the Institute for the Promotion of Innovation through Science and Technology in Flanders (IWT-Vlaanderen), and the Research Foundation Flanders (grant no. GNM-B5996KAN2006) for funding. Patrizia d'Ettorre was supported by an EU Marie Curie Excellence Grant CODICES-EXT-CT-2004-014202.

\section{References}

AITCHISON, J. 1986. The Statistical Analysis of Compositional Data. Chapman and Hall, London.

BAGNÈRES, A.-G. and BLOMQUIST, G. J. 2010. Site of synthesis, mechanism of transport and selective deposition of hydrocarbons, pp. 75-99, in G. J. Blomquist and A.-G. Bagnères (eds.), Insect Hydrocarbons: Biology, Biochemistry, and Chemical Ecology. Cambridge University Press, Cambridge.

BILLEN, J. P. J. 1987. New structural aspects of the Dufour's and venom glands in social insects. Naturwissenschaften 74:340-341.

BILLEN, J. 2006. Morphology and ultrastructure of the Dufour gland in workers of social wasps (Hymenoptera, Vespidae). Arthropod. Struct. Dev. 35:77-84

BLOCH, G., BORST, D. W., HUANG, Z. Y., ROBINSON, G. E., CNAANI, J., and HEFETZ, A. 2000. Juvenile hormone titers, juvenile hormone biosynthesis, ovarian development and social environment in Bombus terrestris. J. Insect Physiol. 46:47-57.

BONAVITA-COUGOURDAN, A., CLÉMENT, J. L., and LANGE, C. 1987. Nestmate recognition: The role of cuticular hydrocarbons in the ant Camponotus vagus Scop. J. Entomol. Sci. 22:1-10.

BONAVITA-COUGOURDAN, A., THERAULAZ, G., BAGNĖRES, A.-G., ROUX, M., PRATTE, M., PROVOST, E., and CLÉMENT, J.-L. 1991. Cuticular hydrocarbons, social organization and ovarian development in a Polistine wasp: Polistes dominulus Christ. Comp. Biochem. Physiol. B 100:667-680.

BUTTS, D. P., ESPELIE, K. E., and HERMANN, H. R. 1991. Cuticular hydrocarbons of four species of social wasps in the subfamily VespinaeVespa crabro L, Dolichovespula maculata (L), Vespula squamosa (Drury) and Vespula maculifrons (Buysson). Comp. Biochem. Physiol. B 99:87-91.

DANI, F. R., MORGAN, E. D., and TURILlazZI, S. 1996. Dufour gland secretion of Polistes wasp: Chemical composition and possible involvement in nestmate recognition (Hymenoptera: vespidae). $J$. Insect Physiol. 42:541-548.

DAPPORTO, L., DANI, F. R., and TURILLAZZI, S. 2007. Social dominance molds cuticular and egg chemical blends in a paper wasp. Curr. Biol. 17:R504-R505.

DE BISEAU, J. C., PASSERA, L., DALOZE, D., and ARON, S. 2004. Ovarian activity correlates with extreme changes in cuticular hydrocarbon profile in the highly polygynous ant, Linepithema humile. $J$. Insect Physiol. 50:585-593.

D'ETTORRE, P., HEINZE, J., and RATNIEKS, F. L. W. 2004a. Worker policing by egg-eating in the ponerine ant Pachycondyla inversa. Proc. $R$. Soc. Lond. B Biol. Sci. 271:1427-1434.

D'ETTORRE, P., HEINZE, E., SCHULZ, C., FRANCKE, W., and AYASSE, M. 2004b. Does she smell like a queen? Chemoreception of a cuticular hydrocarbon signal in the ant Pachycondyla inversa. J. Exp. Biol. 207:1085-1091.

DIETEMANN, V., PEETERS, C., LIEBIG, J., THIVET, V., and HÖLLDOBLER, B. 2003. Cuticular hydrocarbons mediate discrimination of reproductives and nonreproductives in the ant Myrmecia gulosa. Proc. Natl. Acad. Sci. U. S. A. 100:10341-10346.

ENDLER, A., LIEBIG, J., SCHMITT, T., PARKER, J. E., JONES, G. R., SCHREIER, P., and HÖLLDOBLER, B. 2004. Surface hydrocarbons of queen eggs regulate worker reproduction in a social insect. Proc. Natl. Acad. Sci. U. S. A. 101:2945-2950.
ENDLER, A., LIEBIG, J., and HÖLLDOBLER, B. 2006. Queen fertility, egg marking and colony size in the ant Camponotus floridanus. Behav. Ecol. Sociobiol. 59:490-499.

FAN, Y. L., CHASE, J., SEVALA, V. L., and SCHAL, C. 2002. Lipophorinfacilitated hydrocarbon uptake by oocytes in the German cockroach Blattella germanica (L.). J. Exp. Biol. 205:781-790.

FOSTER, K. R. and RATNIEKS, F. L. W. 2001. Convergent evolution of worker policing by egg eating in the honeybee and common wasp. Proc. R. Soc. Lond. B 268:169-174.

HEINZE, J., STENGL, B., and SLEDGE, M. F. 2002. Worker rank, reproductive status and cuticular hydrocarbon signature in the ant, Pachycondyla cf. inversa. Behav. Ecol. Sociobiol. 52:59-65.

HÖLLDOBLER, B. and WILSON, E. O. 2009. The Superorganism: The Beauty, Elegance, and Strangeness of Insect Societies. W.W. Norton \& Company, New York.

HOLMAN, L., DREIER, S., and D'ETTORRE, P. 2010a. Selfish strategies and honest signalling: Reproductive conflicts in ant queen associations. Proc. R. Soc. B 277:2007-2015.

HOLMAN, L., JORGENSEN, C. G., NIELSEN, J., and D'ETTORRE, P. $2010 \mathrm{~b}$. Identification of an ant queen pheromone regulating worker sterility. Proc. R. Soc. B 277:3793-3800.

HORA, R. R., IONESCU-HIRSH, A., SIMON, T., DELABIE, J., ROBERT, J., FRESNEAU, D., and HEFETZ, A. 2008. Postmating changes in cuticular chemistry and visual appearance in Ectatomma tuberculatum queens (Formicidae: Ectatomminae). Naturwissenschaften 95:5560.

HOWARD, R. W., PEREZ-LACHAUD, G., and LACHAUD, J. P. 2001. Cuticular hydrocarbons of Kapala sulcifacies (Hymenoptera: Eucharitidae) and its host, the ponerine ant Ectatomma ruidum (Hymenoptera: Formicidae). Ann. Entomol. Soc. Am. 94:707-716.

HUANG, Z. Y., ROBINSON, G. E., and BORST, D. W. 1994. Physiological correlates of division of labor among similarly aged honey bees. J. Comp. Physiol. A. 174:731-739.

KATZAV-GOZANSKY, T., SOROKER, V., HEFETZ, A., COJOCARU, M., ERDMANN, D. H., and FRANCKE, W. 1997. Plasticity of castespecific Dufour's gland secretion in the honey bee (Apis mellifera L). Naturwissenschaften 84:238-241.

KATZAV-GOZANSKY, T., SOROKER, V., IBARRA, F., FRANCKE, W., and HEFETZ, A. 2001. Dufour's gland secretion of the queen honeybee (Apis mellifera): An egg discriminator pheromone or a queen signal? Behav. Ecol. Sociobiol. 51:76-86.

LE CONTE, Y. and HEFETZ, A. 2008. Primer pheromones in social Hymenoptera. Annu. Rev. Entomol. 53:523-542.

LENGYEL, F., WESTERLUND, S. A., and KAIB, M. 2007. Juvenile hormone III influences task-specific cuticular hydrocarbon profile changes in the ant Myrmicaria eumenoides. J. Chem. Ecol. 33:167-181.

LIEBIG, J. 2010. Hydrocabon profiles indicate fertility and dominance status in ant, bee, and wasp colonies, pp. 254-281, in G. J. Blomquist and A.-G. Bagnères (eds.), Insect Hydrocarbons: Biology, Biochemistry, and Chemical Ecology. Cambridge University Press, Cambridge.

LOMMELEN, E., JOHNSON, C. A., DRIJFHOUT, F. P., BILLEN, J., and GOBIN, B. 2008. Egg marking in the facultatively queenless ant Gnamptogenys striatula: The source and mechanism. J. Insect Physiol. $54: 727-736$

MARTIN, S. J., JONES, G. R., CHÂLINE, N., MIDDLETON, H., and RATNIEKS, F. L. W. 2002. Reassessing the role of the honeybee (Apis mellifera) Dufour's gland in egg marking. Naturwissenschaften 89:528-532.

MARTIN, S. J., JONES, G. R., CHÂLINE, N., and RATNIEKS, F. L. W. 2004. Role of hydrocarbons in egg recognition in the honeybee. Physiol. Entomol. 29:395-399.

MeUnier, J., Delemont, O., and LuCAS, C. 2011. Recognition in ants: Social origin matters. Plos One 6.

MITRA, A. and GADAGKAR, R. 2011. Can Dufour's gland compounds honestly signal fertility in the primitively eusocial wasp Ropalidia marginata? Naturwissenschaften 98:157-161. 
MITRA, A., SAHA, P., CHAOULIDEER, M. E., BHADRA, A., and GADAGKAR, R. 2011. Chemical communication in Ropalidia marginata: Dufour's gland contains queen signal that is perceived across colonies and does not contain colony signal. J. Insect Physiol. 57:280-284.

MONNIN, T. 2006. Chemical recognition of reproductive status in social insects. Ann. Zool. Fenn. 43:515-530.

MONNIN, T. and PEETERS, C. 1997. Cannibalism of subordinates' eggs in the monogynous queenless ant Dinoponera quadriceps. Naturwissenschaften 84:499-502.

QUELLER, D. C. and STRASSMANN, J. E. 2009. Beyond society: The evolution of organismality. Phil. Trans. R. Soc. Lond. B 364:3143-3155.

RATNIEKS, F. L. W. 1995. Evidence for a queen-produced egg-marking pheromone and its use in worker policing in the honey-bee. $J$. Apic. Res. 34:31-37.

RATNIEKS, F. L. W. and VISSCHER, P. K. 1989. Worker policing in the honeybee. Nature 342:796-797.

RATNIEKS, F. L. W. and WENSELEERS, T. 2008. Altruism in insect societies and beyond: Voluntary or enforced? Trends Ecol. Evol. 23:45-52.
RATNIEKS, F. L. W., FOSTER, K. R., and WENSELEERS, T. 2006. Conflict resolution in insect societies. Annu. Rev. Entomol. 51:581-608.

SCHAL, C., SEVALA, V. L., CAPURRO, M. L., SNYDER, T. E., BLOMQUIST, G. J., and BAGNÈRES, A.-G. 2001. Tissue distribution and lipophorin transport of hydrocarbons and sex pheromones in the house fly, Musca domestica. J. Insect Sci. 1:1-12.

SMITH, A. A., HOLLDOBLER, B., and LIEBIG, J. 2008. Hydrocarbon signals explain the pattern of worker and egg policing in the ant Aphaenogaster cockerelli. J. Chem. Ecol. 34:1275-1282.

SMITH, A. A., HOLldoBER, B., and LIEBIG, J. 2009. Cuticular hydrocarbons reliably identify cheaters and allow enforcement of altruism in a social insect. Curr. Biol. 19:78-81.

STRASSMANN, J. E. and QUELLER, D. C. 2010. The social organism: Congresses, parties, and committees. Evolution 64:605-616.

VAN ZWEDEN, J. S., HEINZE, J., BOOMSMA, J. J., and D'ETTORRE, P. 2009. Ant queen egg-marking signals: Matching deceptive laboratory simplicity with natural complexity. PLoS One 4:4718.

WENSELEERS, T. and RATNIEKS, F. L. W. 2006. Comparative analysis of worker reproduction and policing in eusocial Hymenoptera supports relatedness theory. Am. Nat. 168:E163-E179. 
Table S1. Hydrocarbon composition (\% \pm SD) of the surface of queen-laid (Q-laid) and workerlaid (W-laid) eggs and of the cuticle of reproductive queens (Q), spring-collected queens (SQ), virgin queens (VQ), and workers with fully-developed (FD), partially developed (PD), and undeveloped ovaries (UND) in Vespula vulgaris. For dimethyl alkanes, $\mathrm{x}$ represents the position of the second methyl group. For instance, for peak $6, x=7,9,11$, and 13 is used to denote that peak 6 was composed of a mixture of 5,7-, 5,9-, 5,11-, and 5,13-diMeC 23 . For peaks 45, 46, and 48 , the positions of the methyl groups were not identifiable.

\begin{tabular}{|c|c|c|c|c|c|c|c|c|c|}
\hline $\begin{array}{l}\text { Peak } \\
\text { no. }\end{array}$ & Compound & $\begin{array}{r}\text { Q-laid } \\
\text { eggs } \\
(N= \\
44)\end{array}$ & $\begin{array}{r}\text { W-laid } \\
\text { eggs } \\
(N=39)\end{array}$ & $\begin{array}{r}Q \\
(N= \\
13)\end{array}$ & $\begin{array}{r}\text { SQ } \\
(N=7)\end{array}$ & $\begin{array}{r}\text { VQ } \\
(N=17)\end{array}$ & $\begin{array}{r}\text { FD } \\
(N=44)\end{array}$ & $\begin{array}{r}\text { PD } \\
(N=8)\end{array}$ & $\begin{array}{r}\text { UND } \\
(N=49)\end{array}$ \\
\hline 1 & $n-C_{23}$ & $\begin{array}{r}2.88 \pm \\
1.02\end{array}$ & $\begin{array}{r}3.66 \pm \\
1.01\end{array}$ & $\begin{array}{r}0.88 \pm \\
0.37\end{array}$ & $\begin{array}{r}1.29 \pm \\
0.71\end{array}$ & $\begin{array}{r}2.75 \pm \\
1.41\end{array}$ & $\begin{array}{r}2.54 \pm \\
0.62\end{array}$ & $\begin{array}{r}3.02 \pm \\
0.71\end{array}$ & $\begin{array}{r}2.90 \pm \\
0.74\end{array}$ \\
\hline 2 & 9-, $11-\mathrm{MeC}_{23}$ & $\begin{array}{r}0.44 \pm \\
0.19\end{array}$ & $\begin{array}{r}0.92 \pm \\
0.30\end{array}$ & $\begin{array}{r}0.32 \pm \\
0.17\end{array}$ & $\begin{array}{r}0.13 \pm \\
0.09\end{array}$ & $\begin{array}{r}0.25 \pm \\
0.10\end{array}$ & $\begin{array}{r}1.32 \pm \\
0.40\end{array}$ & $\begin{array}{r}1.26 \pm \\
0.13\end{array}$ & $\begin{array}{r}1.28 \pm \\
0.40\end{array}$ \\
\hline 3 & $7-\mathrm{MeC}_{23}$ & $\begin{array}{r}0.15 \pm \\
0.07\end{array}$ & $\begin{array}{r}0.32 \pm \\
0.11\end{array}$ & $\begin{array}{r}0.10 \pm \\
0.05\end{array}$ & $\begin{array}{r}0.02 \pm \\
0.02\end{array}$ & $\begin{array}{r}0.10 \pm \\
0.09\end{array}$ & $\begin{array}{r}0.40 \pm \\
0.14\end{array}$ & $\begin{array}{r}0.39 \pm \\
0.09\end{array}$ & $\begin{array}{r}0.38 \pm \\
0.11\end{array}$ \\
\hline 4 & $5-\mathrm{MeC}_{23}$ & $\begin{array}{r}0.25 \pm \\
0.12\end{array}$ & $\begin{array}{r}0.49 \pm \\
0.16\end{array}$ & $\begin{array}{r}0.17 \pm \\
0.09\end{array}$ & $\begin{array}{r}0.05 \pm \\
0.04\end{array}$ & $\begin{array}{r}0.20 \pm \\
0.15\end{array}$ & $\begin{array}{r}0.74 \pm \\
0.22\end{array}$ & $\begin{array}{r}0.73 \pm \\
0.12\end{array}$ & $\begin{array}{r}0.71 \pm \\
0.20\end{array}$ \\
\hline 5 & $3-\mathrm{MeC}_{23}$ & $\begin{array}{r}1.16 \pm \\
0.55\end{array}$ & $\begin{array}{r}2.27 \pm \\
0.73\end{array}$ & $\begin{array}{r}0.53 \pm \\
0.28\end{array}$ & $\begin{array}{r}0.33 \pm \\
0.17\end{array}$ & $\begin{array}{r}0.56 \pm \\
0.23\end{array}$ & $\begin{array}{r}2.44 \pm \\
0.71\end{array}$ & $\begin{array}{r}2.37 \pm \\
0.41\end{array}$ & $\begin{array}{r}2.34 \pm \\
0.61\end{array}$ \\
\hline 6 & $\begin{array}{l}5, x-\text { diMeC }_{23}(x=7 \\
9,11,13)\end{array}$ & $\begin{array}{r}0.19 \pm \\
0.13\end{array}$ & $\begin{array}{r}0.35 \pm \\
0.13\end{array}$ & $\begin{array}{r}0.13 \pm \\
0.07\end{array}$ & $\begin{array}{r}0.02 \pm \\
0.02\end{array}$ & $\begin{array}{r}0.21 \pm \\
0.21\end{array}$ & $\begin{array}{r}0.43 \pm \\
0.13\end{array}$ & $\begin{array}{r}0.39 \pm \\
0.10\end{array}$ & $\begin{array}{r}0.42 \pm \\
0.14\end{array}$ \\
\hline 7 & $n-\mathrm{C}_{24}$ & $\begin{array}{r}1.68 \pm \\
0.54\end{array}$ & $\begin{array}{r}1.99 \pm \\
0.67\end{array}$ & $\begin{array}{r}1.05 \pm \\
0.23\end{array}$ & $\begin{array}{r}1.08 \pm \\
0.48\end{array}$ & $\begin{array}{r}0.76 \pm \\
0.16\end{array}$ & $\begin{array}{r}2.07 \pm \\
0.41\end{array}$ & $\begin{array}{r}2.37 \pm \\
0.34\end{array}$ & $\begin{array}{r}2.34 \pm \\
0.50\end{array}$ \\
\hline 8 & $\begin{array}{l}3, x-\text { diMeC }_{23} \quad(x=7 \\
9,11,13)\end{array}$ & $\begin{array}{r}0.60 \pm \\
0.38\end{array}$ & $\begin{array}{r}1.09 \pm \\
0.32\end{array}$ & $\begin{array}{r}0.28 \pm \\
0.13\end{array}$ & $\begin{array}{r}0.06 \pm \\
0.04\end{array}$ & $\begin{array}{r}0.41 \pm \\
0.19\end{array}$ & $\begin{array}{r}1.01 \pm \\
0.30\end{array}$ & $\begin{array}{r}0.92 \pm \\
0.24\end{array}$ & $\begin{array}{r}0.99 \pm \\
0.31\end{array}$ \\
\hline 9 & $10-, 12-, 14-\mathrm{MeC}_{24}$ & $\begin{array}{r}0.67 \pm \\
0.31\end{array}$ & $\begin{array}{r}1.19 \pm \\
0.36\end{array}$ & $\begin{array}{r}0.43 \pm \\
0.20\end{array}$ & $\begin{array}{r}0.22 \pm \\
0.16\end{array}$ & $\begin{array}{r}0.48 \pm \\
0.16\end{array}$ & $\begin{array}{r}1.71 \pm \\
0.40\end{array}$ & $\begin{array}{r}1.55 \pm \\
0.27\end{array}$ & $\begin{array}{r}1.68 \pm \\
0.39\end{array}$ \\
\hline 10 & $6-\mathrm{MeC}_{24}$ & $\begin{array}{r}0.18 \pm \\
0.08\end{array}$ & $\begin{array}{r}0.28 \pm \\
0.07\end{array}$ & $\begin{array}{r}0.11 \pm \\
0.05\end{array}$ & $\begin{array}{r}0.04 \pm \\
0.02\end{array}$ & $\begin{array}{r}0.16 \pm \\
0.15\end{array}$ & $\begin{array}{r}0.42 \pm \\
0.11\end{array}$ & $\begin{array}{r}0.54 \pm \\
0.40\end{array}$ & $\begin{array}{r}0.43 \pm \\
0.13\end{array}$ \\
\hline 11 & $4-\mathrm{MeC}_{24}$ & $\begin{array}{r}0.54 \pm \\
0.27\end{array}$ & $\begin{array}{r}0.84 \pm \\
0.19\end{array}$ & $\begin{array}{r}0.29 \pm \\
0.13\end{array}$ & $\begin{array}{r}0.19 \pm \\
0.10\end{array}$ & $\begin{array}{r}0.39 \pm \\
0.12\end{array}$ & $\begin{array}{r}1.15 \pm \\
0.24\end{array}$ & $\begin{array}{r}1.01 \pm \\
0.31\end{array}$ & $\begin{array}{r}1.20 \pm \\
0.29\end{array}$ \\
\hline 12 & $\mathrm{C}_{25: 1}$ (+ isomer) & $\begin{array}{r}1.38 \pm \\
0.77\end{array}$ & $\begin{array}{r}1.56 \pm \\
0.64\end{array}$ & $\begin{array}{r}0.48 \pm \\
0.17\end{array}$ & $\begin{array}{r}1.12 \pm \\
0.81\end{array}$ & $\begin{array}{r}0.36 \pm \\
0.10\end{array}$ & $\begin{array}{r}0.96 \pm \\
0.21\end{array}$ & $\begin{array}{r}1.08 \pm \\
0.23\end{array}$ & $\begin{array}{r}1.05 \pm \\
0.25\end{array}$ \\
\hline 13 & $\begin{array}{l}4, x-\text { diMeC }_{24} \quad(x=8 \\
10,12)\end{array}$ & $\begin{array}{r}0.47 \pm \\
0.26\end{array}$ & $\begin{array}{r}0.68 \pm \\
0.16\end{array}$ & $\begin{array}{r}0.46 \pm \\
0.76\end{array}$ & $\begin{array}{r}0.15 \pm \\
0.05\end{array}$ & $\begin{array}{r}0.40 \pm \\
0.11\end{array}$ & $\begin{array}{r}0.77 \pm \\
0.19\end{array}$ & $\begin{array}{r}0.62 \pm \\
0.27\end{array}$ & $\begin{array}{r}0.76 \pm \\
0.21\end{array}$ \\
\hline
\end{tabular}




\begin{tabular}{|c|c|c|c|c|c|c|c|c|c|}
\hline 14 & $n-C_{25}$ & $\begin{array}{r}16.00 \pm \\
2.99\end{array}$ & $\begin{array}{r}13.11 \pm \\
3.56\end{array}$ & $\begin{array}{r}17.30 \pm \\
2.32\end{array}$ & $\begin{array}{r}18.57 \pm \\
5.19\end{array}$ & $\begin{array}{r}9.28 \pm \\
2.31\end{array}$ & $\begin{array}{r}15.23 \pm \\
2.68\end{array}$ & $\begin{array}{r}17.72 \pm \\
3.60\end{array}$ & $\begin{array}{r}17.17 \pm \\
3.40\end{array}$ \\
\hline 15 & $\begin{array}{l}11-, 13-, 15- \\
\mathrm{MeC}_{25}\end{array}$ & $\begin{array}{r}4.65 \pm \\
1.58\end{array}$ & $\begin{array}{r}6.92 \pm \\
1.28\end{array}$ & $\begin{array}{r}3.32 \pm \\
1.17\end{array}$ & $\begin{array}{r}3.86 \pm \\
1.94\end{array}$ & $\begin{array}{r}4.99 \pm \\
1.51\end{array}$ & $\begin{array}{r}11.12 \pm \\
1.51\end{array}$ & $\begin{array}{r}10.28 \pm \\
1.41\end{array}$ & $\begin{array}{r}10.63 \pm \\
1.35\end{array}$ \\
\hline 16 & $7-\mathrm{MeC}_{25}$ & $\begin{array}{r}0.72 \pm \\
0.24\end{array}$ & $\begin{array}{r}0.98 \pm \\
0.24\end{array}$ & $\begin{array}{r}0.40 \pm \\
0.15\end{array}$ & $\begin{array}{r}0.30 \pm \\
0.14\end{array}$ & $\begin{array}{r}0.86 \pm \\
1.34\end{array}$ & $\begin{array}{r}1.36 \pm \\
0.23\end{array}$ & $\begin{array}{r}1.32 \pm \\
0.27\end{array}$ & $\begin{array}{r}1.30 \pm \\
0.22\end{array}$ \\
\hline 17 & $5-\mathrm{MeC}_{25}$ & $\begin{array}{r}1.31 \pm \\
0.45\end{array}$ & $\begin{array}{r}1.88 \pm \\
0.68\end{array}$ & $\begin{array}{r}0.84 \pm \\
0.30\end{array}$ & $\begin{array}{r}0.67 \pm \\
0.39\end{array}$ & $\begin{array}{r}1.32 \pm \\
0.27\end{array}$ & $\begin{array}{r}2.67 \pm \\
0.28\end{array}$ & $\begin{array}{r}2.70 \pm \\
0.41\end{array}$ & $\begin{array}{r}2.59 \pm \\
0.31\end{array}$ \\
\hline 18 & $3-\mathrm{MeC}_{25}$ & $\begin{array}{r}6.62 \pm \\
1.80\end{array}$ & $\begin{array}{r}6.60 \pm \\
1.50\end{array}$ & $\begin{array}{r}3.02 \pm \\
1.02\end{array}$ & $\begin{array}{r}5.10 \pm \\
1.12\end{array}$ & $\begin{array}{r}3.80 \pm \\
1.00\end{array}$ & $\begin{array}{r}7.77 \pm \\
0.79\end{array}$ & $\begin{array}{r}7.70 \pm \\
1.03\end{array}$ & $\begin{array}{r}7.53 \pm \\
0.87\end{array}$ \\
\hline 19 & $\begin{array}{l}5, x \text {-diMeC } 25(x=9, \\
11,13,15)\end{array}$ & $\begin{array}{r}1.13 \pm \\
0.52\end{array}$ & $\begin{array}{r}1.69 \pm \\
0.31\end{array}$ & $\begin{array}{r}0.74 \pm \\
0.27\end{array}$ & $\begin{array}{r}0.29 \pm \\
0.20\end{array}$ & $\begin{array}{r}1.63 \pm \\
1.03\end{array}$ & $\begin{array}{r}2.09 \pm \\
0.42\end{array}$ & $\begin{array}{r}1.91 \pm \\
0.47\end{array}$ & $\begin{array}{r}1.98 \pm \\
0.38\end{array}$ \\
\hline 20 & $n-C_{26}$ & $\begin{array}{r}2.46 \pm \\
0.61\end{array}$ & $\begin{array}{r}1.82 \pm \\
0.39\end{array}$ & $\begin{array}{r}4.43 \pm \\
0.62\end{array}$ & $\begin{array}{r}2.07 \pm \\
0.14\end{array}$ & $\begin{array}{r}2.05 \pm \\
0.36\end{array}$ & $\begin{array}{r}2.29 \pm \\
0.52\end{array}$ & $\begin{array}{r}2.44 \pm \\
0.39\end{array}$ & $\begin{array}{r}2.39 \pm \\
0.51\end{array}$ \\
\hline 21 & $\begin{array}{l}3, x-\operatorname{diMeC}_{25}(x=9 \\
11,13,15)\end{array}$ & $\begin{array}{r}2.07 \pm \\
1.17\end{array}$ & $\begin{array}{r}3.18 \pm \\
0.61\end{array}$ & $\begin{array}{r}1.28 \pm \\
0.47\end{array}$ & $\begin{array}{r}0.48 \pm \\
0.32\end{array}$ & $\begin{array}{r}2.14 \pm \\
0.42\end{array}$ & $\begin{array}{r}3.85 \pm \\
0.79\end{array}$ & $\begin{array}{r}3.46 \pm \\
0.91\end{array}$ & $\begin{array}{r}3.66 \pm \\
0.75\end{array}$ \\
\hline 22 & $\begin{array}{l}10-,, 12-, 14- \\
\mathrm{MeC}_{26}\end{array}$ & $\begin{array}{r}1.05 \pm \\
0.32\end{array}$ & $\begin{array}{r}1.25 \pm \\
0.23\end{array}$ & $\begin{array}{r}0.73 \pm \\
0.23\end{array}$ & $\begin{array}{r}0.84 \pm \\
0.17\end{array}$ & $\begin{array}{r}1.82 \pm \\
0.46\end{array}$ & $\begin{array}{r}2.00 \pm \\
0.24\end{array}$ & $\begin{array}{r}1.83 \pm \\
0.31\end{array}$ & $\begin{array}{r}1.96 \pm \\
0.28\end{array}$ \\
\hline 23 & $4-\mathrm{MeC}_{26}$ & $\begin{array}{r}0.82 \pm \\
0.11\end{array}$ & $\begin{array}{r}0.80 \pm \\
0.20\end{array}$ & $\begin{array}{r}0.49 \pm \\
0.09\end{array}$ & $\begin{array}{r}0.52 \pm \\
0.09\end{array}$ & $\begin{array}{r}0.83 \pm \\
0.25\end{array}$ & $\begin{array}{r}0.85 \pm \\
0.12\end{array}$ & $\begin{array}{r}0.83 \pm \\
0.11\end{array}$ & $\begin{array}{r}0.88 \pm \\
0.17\end{array}$ \\
\hline 24 & $\mathrm{C}_{27: 1}$ (+isomer) & $\begin{array}{r}2.21 \pm \\
1.24\end{array}$ & $\begin{array}{r}1.85 \pm \\
0.88\end{array}$ & $\begin{array}{r}1.00 \pm \\
0.24\end{array}$ & $\begin{array}{r}2.06 \pm \\
1.14\end{array}$ & $\begin{array}{r}1.69 \pm \\
0.50\end{array}$ & $\begin{array}{r}1.24 \pm \\
0.21\end{array}$ & $\begin{array}{r}1.32 \pm \\
0.12\end{array}$ & $\begin{array}{r}1.38 \pm \\
0.32\end{array}$ \\
\hline 25 & $\begin{array}{l}4, x-\operatorname{diMeC} \\
10,12)\end{array}$ & $\begin{array}{r}0.82 \pm \\
0.35\end{array}$ & $\begin{array}{r}1.16 \pm \\
1.85\end{array}$ & $\begin{array}{r}0.39 \pm \\
0.11\end{array}$ & $\begin{array}{r}0.16 \pm \\
0.04\end{array}$ & $\begin{array}{r}0.96 \pm \\
0.50\end{array}$ & $\begin{array}{r}0.86 \pm \\
0.13\end{array}$ & $\begin{array}{r}0.80 \pm \\
0.12\end{array}$ & $\begin{array}{r}0.84 \pm \\
0.13\end{array}$ \\
\hline 26 & $n-C_{27}$ & $\begin{array}{r}14.51 \pm \\
3.73\end{array}$ & $\begin{array}{r}11.62 \pm \\
3.49\end{array}$ & $\begin{array}{r}30.01 \pm \\
3.75\end{array}$ & $\begin{array}{r}12.72 \pm \\
3.25\end{array}$ & $\begin{array}{r}12.62 \pm \\
1.67\end{array}$ & $\begin{array}{r}7.59 \pm \\
2.89\end{array}$ & $\begin{array}{r}7.61 \pm \\
2.58\end{array}$ & $\begin{array}{r}7.37 \pm \\
2.26\end{array}$ \\
\hline 27 & $11-, 13-\mathrm{MeC}_{27}$ & $\begin{array}{r}3.87 \pm \\
1.35\end{array}$ & $\begin{array}{r}4.09 \pm \\
1.28\end{array}$ & $\begin{array}{r}2.50 \pm \\
0.83\end{array}$ & $\begin{array}{r}4.89 \pm \\
1.50\end{array}$ & $\begin{array}{r}6.70 \pm \\
1.72\end{array}$ & $\begin{array}{r}5.13 \pm \\
0.89\end{array}$ & $\begin{array}{r}4.86 \pm \\
0.58\end{array}$ & $\begin{array}{r}4.85 \pm \\
0.98\end{array}$ \\
\hline 28 & $7-\mathrm{MeC}_{27}$ & $\begin{array}{r}0.55 \pm \\
0.32\end{array}$ & $\begin{array}{r}0.33 \pm \\
0.10\end{array}$ & $\begin{array}{r}0.30 \pm \\
0.10\end{array}$ & $\begin{array}{r}0.34 \pm \\
0.05\end{array}$ & $\begin{array}{r}0.53 \pm \\
0.11\end{array}$ & $\begin{array}{r}0.38 \pm \\
0.06\end{array}$ & $\begin{array}{r}0.39 \pm \\
0.10\end{array}$ & $\begin{array}{r}0.37 \pm \\
0.08\end{array}$ \\
\hline 29 & $5-\mathrm{MeC}_{27}$ & $\begin{array}{r}1.00 \pm \\
0.50\end{array}$ & $\begin{array}{r}1.32 \pm \\
1.71\end{array}$ & $\begin{array}{r}0.38 \pm \\
0.12\end{array}$ & $\begin{array}{r}0.33 \pm \\
0.10\end{array}$ & $\begin{array}{r}0.57 \pm \\
0.17\end{array}$ & $\begin{array}{r}0.50 \pm \\
0.15\end{array}$ & $\begin{array}{r}0.51 \pm \\
0.13\end{array}$ & $\begin{array}{r}0.48 \pm \\
0.20\end{array}$ \\
\hline 30 & $11,15-$ diMeC $_{27}$ & $\begin{array}{r}0.66 \pm \\
0.20\end{array}$ & $\begin{array}{r}0.80 \pm \\
0.34\end{array}$ & $\begin{array}{r}0.74 \pm \\
1.15\end{array}$ & $\begin{array}{r}0.73 \pm \\
0.33\end{array}$ & $\begin{array}{r}0.68 \pm \\
0.11\end{array}$ & $\begin{array}{r}0.72 \pm \\
0.12\end{array}$ & $\begin{array}{r}0.71 \pm \\
0.20\end{array}$ & $\begin{array}{r}0.75 \pm \\
0.16\end{array}$ \\
\hline 31 & $3-\mathrm{MeC}_{27}$ & $\begin{array}{r}5.90 \pm \\
1.52\end{array}$ & $\begin{array}{r}3.26 \pm \\
0.73\end{array}$ & $\begin{array}{r}4.76 \pm \\
1.66\end{array}$ & $\begin{array}{r}5.83 \pm \\
1.84\end{array}$ & $\begin{array}{r}4.67 \pm \\
0.49\end{array}$ & $\begin{array}{r}3.30 \pm \\
0.78\end{array}$ & $\begin{array}{r}3.24 \pm \\
0.48\end{array}$ & $\begin{array}{r}3.06 \pm \\
0.75\end{array}$ \\
\hline 3 & $5, x-d$ & $0.59 \pm$ & $0.71 \pm$ & $0.52 \pm$ & $0.21 \pm$ & $0.98 \pm$ & $0.73 \pm$ & $0.67 \pm$ & $0.69 \pm$ \\
\hline
\end{tabular}




\begin{tabular}{|c|c|c|c|c|c|c|c|c|c|}
\hline & $(x=11,13,15)$ & 0.21 & 0.18 & 0.47 & 0.07 & 0.24 & 0.17 & 0.14 & 0.17 \\
\hline 33 & $n-C_{28}$ & $\begin{array}{r}1.09 \pm \\
0.35\end{array}$ & $\begin{array}{r}0.98 \pm \\
0.30\end{array}$ & $\begin{array}{r}2.22 \pm \\
0.63\end{array}$ & $\begin{array}{r}0.89 \pm \\
0.24\end{array}$ & $\begin{array}{r}1.34 \pm \\
0.35\end{array}$ & $\begin{array}{r}0.59 \pm \\
0.26\end{array}$ & $\begin{array}{r}0.89 \pm \\
1.01\end{array}$ & $\begin{array}{r}0.53 \pm \\
0.16\end{array}$ \\
\hline 34 & $\begin{array}{l}3, x-\operatorname{diMeC}_{27} \\
(x=11,13,15)\end{array}$ & $\begin{array}{r}1.72 \pm \\
0.73\end{array}$ & $\begin{array}{r}2.32 \pm \\
0.45\end{array}$ & $\begin{array}{r}0.89 \pm \\
0.42\end{array}$ & $\begin{array}{r}0.70 \pm \\
0.21\end{array}$ & $\begin{array}{r}2.95 \pm \\
0.76\end{array}$ & $\begin{array}{r}2.63 \pm \\
0.49\end{array}$ & $\begin{array}{r}2.13 \pm \\
0.99\end{array}$ & $\begin{array}{r}2.48 \pm \\
0.48\end{array}$ \\
\hline 35 & $\begin{array}{l}10-, 12-, 14-, 16- \\
\mathrm{MeC}_{28}\end{array}$ & $\begin{array}{r}0.55 \pm \\
0.17\end{array}$ & $\begin{array}{r}0.50 \pm \\
0.19\end{array}$ & $\begin{array}{r}0.34 \pm \\
0.11\end{array}$ & $\begin{array}{r}0.67 \pm \\
0.14\end{array}$ & $\begin{array}{r}1.26 \pm \\
0.28\end{array}$ & $\begin{array}{r}0.57 \pm \\
0.11\end{array}$ & $\begin{array}{r}0.52 \pm \\
0.08\end{array}$ & $\begin{array}{r}0.56 \pm \\
0.13\end{array}$ \\
\hline 36 & $4-\mathrm{MeC}_{28}$ & $\begin{array}{r}0.28 \pm \\
0.12\end{array}$ & $\begin{array}{r}0.36 \pm \\
0.18\end{array}$ & $\begin{array}{r}0.24 \pm \\
0.06\end{array}$ & $\begin{array}{r}0.09 \pm \\
0.05\end{array}$ & $\begin{array}{r}0.23 \pm \\
0.06\end{array}$ & $\begin{array}{r}0.10 \pm \\
0.03\end{array}$ & $\begin{array}{r}0.10 \pm \\
0.02\end{array}$ & $\begin{array}{r}0.11 \pm \\
0.05\end{array}$ \\
\hline 37 & $\mathrm{C}_{29: 1}$ & $\begin{array}{r}1.31 \pm \\
0.70\end{array}$ & $\begin{array}{r}0.73 \pm \\
0.24\end{array}$ & $\begin{array}{r}0.82 \pm \\
0.15\end{array}$ & $\begin{array}{r}2.16 \pm \\
1.35\end{array}$ & $\begin{array}{r}1.88 \pm \\
0.35\end{array}$ & $\begin{array}{r}0.73 \pm \\
0.23\end{array}$ & $\begin{array}{r}0.85 \pm \\
0.13\end{array}$ & $\begin{array}{r}0.82 \pm \\
0.32\end{array}$ \\
\hline 38 & $\begin{array}{l}4, x-\operatorname{diMeC}_{28}(x=8 \\
10,12)\end{array}$ & $\begin{array}{r}0.28 \pm \\
0.29\end{array}$ & $\begin{array}{r}0.31 \pm \\
0.10\end{array}$ & $\begin{array}{r}0.23 \pm \\
0.04\end{array}$ & $\begin{array}{r}0.09 \pm \\
0.03\end{array}$ & $\begin{array}{r}0.54 \pm \\
0.16\end{array}$ & $\begin{array}{r}0.32 \pm \\
0.08\end{array}$ & $\begin{array}{r}0.29 \pm \\
0.05\end{array}$ & $\begin{array}{r}0.31 \pm \\
0.09\end{array}$ \\
\hline 39 & $n-C_{29}$ & $\begin{array}{r}7.11 \pm \\
3.31\end{array}$ & $\begin{array}{r}8.04 \pm \\
3.95\end{array}$ & $\begin{array}{r}6.46 \pm \\
1.53\end{array}$ & $\begin{array}{r}5.18 \pm \\
1.69\end{array}$ & $\begin{array}{r}5.13 \pm \\
1.16\end{array}$ & $\begin{array}{r}1.27 \pm \\
0.58\end{array}$ & $\begin{array}{r}1.18 \pm \\
0.40\end{array}$ & $\begin{array}{r}1.20 \pm \\
0.57\end{array}$ \\
\hline 40 & $\begin{array}{l}11-, 13-, 15- \\
\mathrm{MeC}_{29}\end{array}$ & $\begin{array}{r}1.88 \pm \\
0.84\end{array}$ & $\begin{array}{r}1.48 \pm \\
0.67\end{array}$ & $\begin{array}{r}0.91 \pm \\
0.26\end{array}$ & $\begin{array}{r}3.44 \pm \\
1.02\end{array}$ & $\begin{array}{r}3.31 \pm \\
0.48\end{array}$ & $\begin{array}{r}1.00 \pm \\
0.25\end{array}$ & $\begin{array}{r}0.96 \pm \\
0.12\end{array}$ & $\begin{array}{r}0.93 \pm \\
0.23\end{array}$ \\
\hline 41 & $7-\mathrm{MeC}_{29}$ & $\begin{array}{r}0.72 \pm \\
0.34\end{array}$ & $\begin{array}{r}0.64 \pm \\
0.39\end{array}$ & $\begin{array}{r}0.32 \pm \\
0.09\end{array}$ & $\begin{array}{r}0.50 \pm \\
0.17\end{array}$ & $\begin{array}{r}0.84 \pm \\
0.13\end{array}$ & $\begin{array}{r}0.24 \pm \\
0.05\end{array}$ & $\begin{array}{r}0.23 \pm \\
0.05\end{array}$ & $\begin{array}{r}0.24 \pm \\
0.06\end{array}$ \\
\hline 42 & 3-MeC 29 & $\begin{array}{r}1.58 \pm \\
0.93\end{array}$ & $\begin{array}{r}0.67 \pm \\
0.15\end{array}$ & $\begin{array}{r}3.30 \pm \\
0.94\end{array}$ & $\begin{array}{r}7.36 \pm \\
2.86\end{array}$ & $\begin{array}{r}2.53 \pm \\
1.92\end{array}$ & $\begin{array}{r}0.46 \pm \\
0.19\end{array}$ & $\begin{array}{r}0.44 \pm \\
0.13\end{array}$ & $\begin{array}{r}0.41 \pm \\
0.15\end{array}$ \\
\hline 43 & 5,9-diMeC 29 & $\begin{array}{r}0.64 \pm \\
0.58\end{array}$ & $\begin{array}{r}0.43 \pm \\
0.12\end{array}$ & $\begin{array}{r}0.21 \pm \\
0.06\end{array}$ & $\begin{array}{r}0.18 \pm \\
0.05\end{array}$ & $\begin{array}{r}0.62 \pm \\
0.13\end{array}$ & $\begin{array}{r}0.41 \pm \\
0.10\end{array}$ & $\begin{array}{r}0.38 \pm \\
0.07\end{array}$ & $\begin{array}{r}0.39 \pm \\
0.09\end{array}$ \\
\hline 44 & $n-C_{30}$ & $\begin{array}{r}0.67 \pm \\
0.16\end{array}$ & $\begin{array}{r}0.75 \pm \\
0.17\end{array}$ & $\begin{array}{r}0.54 \pm \\
0.09\end{array}$ & $\begin{array}{r}0.76 \pm \\
0.22\end{array}$ & $\begin{array}{r}1.25 \pm \\
0.21\end{array}$ & $\begin{array}{r}0.63 \pm \\
0.11\end{array}$ & $\begin{array}{r}0.60 \pm \\
0.10\end{array}$ & $\begin{array}{r}0.59 \pm \\
0.11\end{array}$ \\
\hline 45 & $\mathrm{x}_{1}-\mathrm{MeC}_{30}$ & $\begin{array}{r}0.09 \pm \\
0.30\end{array}$ & $\begin{array}{r}0.19 \pm \\
0.47\end{array}$ & $\begin{array}{r}1.26 \pm \\
0.43\end{array}$ & $\begin{array}{r}2.31 \pm \\
0.86\end{array}$ & $\begin{array}{r}4.11 \pm \\
0.90\end{array}$ & $\begin{array}{r}3.88 \pm \\
1.55\end{array}$ & $\begin{array}{r}3.46 \pm \\
1.42\end{array}$ & $\begin{array}{r}3.49 \pm \\
1.11\end{array}$ \\
\hline 46 & $x, y-\operatorname{diMeC}_{30}$ & $\begin{array}{r}0.30 \pm \\
0.14\end{array}$ & $\begin{array}{r}0.32 \pm \\
0.17\end{array}$ & $\begin{array}{r}0.19 \pm \\
0.05\end{array}$ & $\begin{array}{r}0.14 \pm \\
0.04\end{array}$ & $\begin{array}{r}0.34 \pm \\
0.09\end{array}$ & $\begin{array}{r}0.01 \pm \\
0.02\end{array}$ & $\mathrm{nd}^{\mathrm{a}}$ & $\begin{array}{r}0.07 \pm \\
0.09\end{array}$ \\
\hline 47 & $C_{31: 1}$ & $\begin{array}{r}0.61 \pm \\
0.32\end{array}$ & $\begin{array}{r}0.38 \pm \\
0.18\end{array}$ & $\begin{array}{r}0.54 \pm \\
0.10\end{array}$ & $\begin{array}{r}1.10 \pm \\
0.67\end{array}$ & $\begin{array}{r}1.10 \pm \\
0.20\end{array}$ & $\begin{array}{r}0.43 \pm \\
0.12\end{array}$ & $\begin{array}{r}0.45 \pm \\
0.08\end{array}$ & $\begin{array}{r}0.46 \pm \\
0.22\end{array}$ \\
\hline 48 & $\mathrm{x}_{2}-\mathrm{MeC}_{30}$ & $\begin{array}{r}0.03 \pm \\
0.06\end{array}$ & $\begin{array}{r}0.07 \pm \\
0.08\end{array}$ & $\begin{array}{r}0.08 \pm \\
0.01\end{array}$ & $\begin{array}{r}0.11 \pm \\
0.03\end{array}$ & $\begin{array}{r}0.20 \pm \\
0.04\end{array}$ & $\begin{array}{r}0.12 \pm \\
0.12\end{array}$ & $\begin{array}{r}0.10 \pm \\
0.02\end{array}$ & $\begin{array}{r}0.11 \pm \\
0.04\end{array}$ \\
\hline 49 & $n-C_{31}$ & $\begin{array}{r}1.23 \pm \\
0.67\end{array}$ & $\begin{array}{r}1.42 \pm \\
0.67\end{array}$ & $\begin{array}{r}0.70 \pm \\
0.19\end{array}$ & $\begin{array}{r}1.14 \pm \\
0.42\end{array}$ & $\begin{array}{r}0.91 \pm \\
0.32\end{array}$ & $\begin{array}{r}0.24 \pm \\
0.07\end{array}$ & $\begin{array}{r}0.22 \pm \\
0.06\end{array}$ & $\begin{array}{r}0.24 \pm \\
0.11\end{array}$ \\
\hline 50 & $\begin{array}{l}11-, 13-, 15- \\
\mathrm{MeC}_{31}\end{array}$ & $\begin{array}{r}0.89 \pm \\
0.57\end{array}$ & $\begin{array}{r}0.65 \pm \\
0.40\end{array}$ & $\begin{array}{r}0.40 \pm \\
0.11\end{array}$ & $\begin{array}{r}3.47 \pm \\
1.60\end{array}$ & $\begin{array}{r}2.83 \pm \\
1.31\end{array}$ & $\begin{array}{r}0.32 \pm \\
0.12\end{array}$ & $\begin{array}{r}0.30 \pm \\
0.05\end{array}$ & $\begin{array}{r}0.30 \pm \\
0.10\end{array}$ \\
\hline
\end{tabular}




\begin{tabular}{|c|c|c|c|c|c|c|c|c|c|}
\hline 51 & $\begin{array}{l}\text { 11,17-, 13,17-- } \\
\text { 15,19-diMeC } 31\end{array}$ & $\begin{array}{r}1.52 \pm \\
0.81\end{array}$ & $\begin{array}{r}0.78 \pm \\
0.54\end{array}$ & $\begin{array}{r}1.98 \pm \\
0.43\end{array}$ & $\begin{array}{r}5.04 \pm \\
1.69\end{array}$ & $\begin{array}{r}3.46 \pm \\
2.37\end{array}$ & $\begin{array}{r}0.42< \pm \\
0.26\end{array}$ & $\begin{array}{r}0.35 \pm \\
0.05\end{array}$ & $\begin{array}{r}0.38 \pm \\
0.13\end{array}$ \\
\hline $\begin{array}{l}\text { Sho } \\
b\end{array}$ & r-chained $n$-alkanes & $\begin{array}{r}37.53 \pm \\
6.70\end{array}$ & $\begin{array}{r}32.19 \pm \\
6.19\end{array}$ & $\begin{array}{r}53.67 \pm \\
4.63\end{array}$ & $\begin{array}{r}35.72 \pm \\
3.69\end{array}$ & $\begin{array}{r}27.46 \pm \\
3.14\end{array}$ & $\begin{array}{r}29.71 \pm \\
5.02\end{array}$ & $\begin{array}{r}33.16 \pm \\
7.17\end{array}$ & $\begin{array}{r}32.17 \pm \\
5.63\end{array}$ \\
\hline $\begin{array}{l}\text { Lon } \\
c\end{array}$ & r-chained $n$-alkanes & $\begin{array}{r}10.10 \pm \\
4.21\end{array}$ & $\begin{array}{r}11.19 \pm \\
4.83\end{array}$ & $\begin{array}{r}9.92 \pm \\
2.08\end{array}$ & $\begin{array}{r}7.97 \pm \\
2.38\end{array}$ & $\begin{array}{r}8.64 \pm \\
1.88\end{array}$ & $\begin{array}{r}2.73 \pm \\
0.92\end{array}$ & $\begin{array}{r}2.89 \pm \\
1.14\end{array}$ & $\begin{array}{r}2.56 \pm \\
0.85\end{array}$ \\
\hline Sho & er-chained alkenes ${ }^{\mathrm{b}}$ & $\begin{array}{r}3.59 \pm \\
1.97\end{array}$ & $\begin{array}{r}3.42 \pm \\
1.32\end{array}$ & $\begin{array}{r}1.48 \pm \\
0.37\end{array}$ & $\begin{array}{r}3.18 \pm \\
1.92\end{array}$ & $\begin{array}{r}2.05 \pm \\
0.54\end{array}$ & $\begin{array}{r}2.20 \pm \\
0.29\end{array}$ & $\begin{array}{r}2.40 \pm \\
0.33\end{array}$ & $\begin{array}{r}2.43 \pm \\
0.45\end{array}$ \\
\hline Lon & r-chained alkenes ${ }^{c}$ & $\begin{array}{r}1.92 \pm \\
0.97\end{array}$ & $\begin{array}{r}1.11 \pm \\
0.39\end{array}$ & $\begin{array}{r}1.36 \pm \\
0.23\end{array}$ & $\begin{array}{r}3.26 \pm \\
2.00\end{array}$ & $\begin{array}{r}2.98 \pm \\
0.33\end{array}$ & $\begin{array}{r}1.16 \pm \\
0.32\end{array}$ & $\begin{array}{r}1.30 \pm \\
0.20\end{array}$ & $\begin{array}{r}1.28 \pm \\
0.52\end{array}$ \\
\hline $\begin{array}{l}\text { Sho } \\
\text { metl }\end{array}$ & $\begin{array}{l}\text { er-chained } \\
\text { lated alkanes }\end{array}$ & $\begin{array}{r}38.12 \pm \\
7.70\end{array}$ & $\begin{array}{r}45.70 \pm \\
6.59\end{array}$ & $\begin{array}{r}24.11 \pm \\
5.41\end{array}$ & $\begin{array}{r}26.47 \pm \\
4.06\end{array}$ & $\begin{array}{r}38.61 \pm \\
6.09\end{array}$ & $\begin{array}{r}56.36 \pm \\
5.44\end{array}$ & $\begin{array}{r}53.11 \pm \\
6.76\end{array}$ & $\begin{array}{r}54.24 \pm \\
5.47\end{array}$ \\
\hline $\begin{array}{l}\text { Lon } \\
\text { metl }\end{array}$ & $\begin{array}{l}\text {-chained } \\
\text { ated alkanes }\end{array}$ & $\begin{array}{r}8.74 \pm \\
3.32\end{array}$ & $\begin{array}{r}6.39 \pm \\
2.87\end{array}$ & $\begin{array}{r}9.45 \pm \\
1.54\end{array}$ & $\begin{array}{r}23.39 \pm \\
6.20\end{array}$ & $\begin{array}{r}20.27 \pm \\
4.52\end{array}$ & $\begin{array}{r}7.85 \pm \\
1.77\end{array}$ & $\begin{array}{r}7.14 \pm \\
1.65\end{array}$ & $\begin{array}{r}7.31 \pm \\
1.45\end{array}$ \\
\hline
\end{tabular}

\footnotetext{
${ }^{\mathrm{a}}$ not detectable

${ }^{b}$ shorter-chained: $\mathrm{C}_{23}-\mathrm{C}_{27}$

${ }^{\mathrm{c}}$ longer-chained: $\mathrm{C}_{28}-\mathrm{C}_{31}$
} 
Table S2. Factor loadings of the hydrocarbon compounds on the six PCs with an eigenvalue greater than 1. For information on the value of $\mathrm{x}$, see Table S1.

\begin{tabular}{|c|c|c|c|c|c|c|c|}
\hline $\begin{array}{l}\mathrm{Pe} \\
\text { ak } \\
\text { no. }\end{array}$ & Component & PC 1 & PC 2 & PC 3 & PC 4 & PC 5 & "PC 6 \\
\hline 1 & $n-C_{23}$ & 0.36 & -0.64 & -0.24 & 0.07 & -0.18 & -0.28 \\
\hline 2 & $9-, 11-\mathrm{MeC}_{23}$ & 0.96 & -0.08 & -0.08 & -0.04 & 0.08 & -0.08 \\
\hline 3 & $7-\mathrm{MeC}_{23}$ & 0.92 & -0.18 & -0.12 & -0.03 & 0.03 & -0.09 \\
\hline 4 & $5-\mathrm{MeC}_{23}$ & 0.92 & -0.14 & -0.11 & 0.03 & 0.02 & -0.13 \\
\hline 5 & $3-\mathrm{MeC}_{23}$ & 0.94 & -0.23 & -0.10 & -0.08 & 0.04 & -0.06 \\
\hline 6 & $5, x-$ diMeC $_{23}$ & 0.94 & 0.01 & 0.03 & -0.13 & -0.10 & -0.09 \\
\hline 7 & $n-C_{24}$ & 0.53 & -0.66 & -0.42 & 0.13 & 0.07 & 0.00 \\
\hline 8 & $3, \mathrm{x}-\mathrm{diMeC}_{23}$ & 0.94 & -0.09 & 0.04 & -0.22 & -0.12 & -0.09 \\
\hline 9 & $\begin{array}{l}\text { 10-,12-,14- } \\
\mathrm{MeC}_{24}\end{array}$ & 0.97 & -0.03 & 0.04 & -0.05 & 0.09 & -0.06 \\
\hline 10 & $6-\mathrm{MeC}_{24}$ & 0.94 & -0.12 & -0.04 & 0.01 & 0.04 & -0.06 \\
\hline 11 & $4-\mathrm{MeC}_{24}$ & 0.94 & -0.18 & -0.02 & -0.01 & 0.07 & 0.01 \\
\hline 12 & $\mathrm{C}_{25: 1}$ (+ isomer) & 0.58 & -0.21 & 0.04 & -0.53 & 0.35 & -0.21 \\
\hline 13 & $4, \mathrm{x}-\mathrm{diMeC}_{24}$ & 0.89 & -0.12 & 0.06 & -0.16 & -0.11 & -0.01 \\
\hline 14 & $n-C_{25}$ & 0.09 & -0.74 & -0.44 & 0.22 & 0.19 & 0.07 \\
\hline 15 & $\begin{array}{l}11-, 1^{-}, 15- \\
\mathrm{MeC}_{25}\end{array}$ & 0.92 & 0.00 & 0.20 & 0.07 & 0.23 & -0.04 \\
\hline 16 & $7-\mathrm{MeC}_{25}$ & 0.84 & -0.18 & 0.12 & 0.04 & 0.19 & -0.10 \\
\hline 17 & $5-\mathrm{MeC}_{25}$ & 0.88 & -0.31 & 0.04 & 0.20 & 0.10 & 0.04 \\
\hline 18 & $3-\mathrm{MeC}_{25}$ & 0.71 & -0.40 & 0.02 & -0.18 & 0.35 & 0.17 \\
\hline 19 & $5, x$-diMeC 25 & 0.91 & -0.01 & 0.26 & -0.05 & -0.14 & -0.03 \\
\hline 20 & $n-C_{26}$ & -0.30 & -0.70 & -0.41 & 0.37 & 0.07 & 0.14 \\
\hline 21 & $3, \mathrm{x}-\mathrm{diMeC}_{25}$ & 0.94 & -0.06 & 0.19 & -0.07 & -0.11 & 0.00 \\
\hline 22 & $\begin{array}{l}10-, 12-, 14- \\
\mathrm{MeC}_{26}\end{array}$ & 0.67 & 0.07 & 0.58 & 0.29 & 0.22 & -0.07 \\
\hline 23 & $4-\mathrm{MeC}_{26}$ & 0.23 & -0.52 & 0.22 & -0.08 & 0.38 & 0.44 \\
\hline 24 & $\mathrm{C}_{27: 1}$ (+isomer) & -0.32 & -0.26 & 0.31 & -0.33 & 0.38 & -0.32 \\
\hline 25 & $4, x-\operatorname{diMeC}_{26}$ & 0.66 & -0.38 & 0.22 & -0.07 & -0.30 & -0.07 \\
\hline 26 & $n-C_{27}$ & -0.69 & -0.58 & -0.29 & 0.22 & -0.06 & -0.01 \\
\hline 27 & $11-, 13-\mathrm{MeC}_{27}$ & -0.22 & -0.24 & 0.66 & 0.44 & 0.25 & -0.06 \\
\hline 28 & $7-\mathrm{MeC}_{27}$ & -0.55 & -0.37 & 0.27 & 0.13 & 0.47 & -0.11 \\
\hline 29 & $5-\mathrm{MeC}_{27}$ & -0.22 & -0.67 & 0.12 & -0.14 & -0.15 & 0.20 \\
\hline 30 & $11,15-$ diMeC $_{27}$ & 0.20 & -0.21 & 0.46 & -0.19 & 0.16 & 0.59 \\
\hline 31 & $3-\mathrm{MeC}_{27}$ & -0.75 & -0.46 & -0.01 & 0.05 & 0.28 & 0.05 \\
\hline 32 & $5, x-$ diMeC $_{27}$ & 0.46 & -0.13 & 0.67 & 0.05 & -0.24 & 0.05 \\
\hline 33 & $n-C_{28}$ & -0.74 & -0.51 & -0.22 & 0.21 & -0.15 & -0.01 \\
\hline 34 & $3, x-$ diMeC $_{27}$ & 0.50 & -0.25 & 0.40 & 0.25 & -0.35 & -0.02 \\
\hline 35 & $\begin{array}{l}10-, 12-, 14- \\
16-\mathrm{MeC}_{28}\end{array}$ & -0.51 & 0.10 & 0.69 & 0.16 & 0.05 & -0.06 \\
\hline 36 & $4-\mathrm{MeC}_{28}$ & -0.63 & -0.40 & 0.04 & -0.38 & -0.29 & 0.15 \\
\hline 37 & $\mathrm{C}_{29: 1}$ & -0.84 & -0.20 & 0.15 & 0.13 & 0.25 & -0.19 \\
\hline
\end{tabular}




\begin{tabular}{|c|c|c|c|c|c|c|c|}
\hline 38 & $4, x-\operatorname{diMeC}_{28}$ & 0.09 & -0.20 & 0.51 & 0.35 & -0.55 & 0.02 \\
\hline 39 & $n-C_{29}$ & -0.78 & -0.50 & -0.17 & 0.04 & -0.20 & -0.12 \\
\hline 40 & $\begin{array}{l}11-, 13-, 15- \\
\mathrm{MeC}_{29}\end{array}$ & -0.88 & -0.05 & 0.34 & -0.05 & 0.11 & -0.14 \\
\hline 41 & $7-\mathrm{MeC}_{29}$ & -0.73 & 0.00 & 0.40 & -0.44 & -0.03 & 0.08 \\
\hline 42 & $3-\mathrm{MeC}_{29}$ & -0.93 & -0.06 & -0.05 & -0.07 & 0.16 & 0.00 \\
\hline 43 & 5,9-diMeC 29 & -0.03 & -0.41 & 0.67 & 0.02 & -0.18 & -0.09 \\
\hline 44 & $n-C_{30}$ & -0.71 & -0.42 & 0.26 & 0.22 & -0.27 & 0.00 \\
\hline 45 & $\mathrm{x}_{1}-\mathrm{MeC}_{30}$ & 0.10 & 0.72 & -0.09 & 0.56 & 0.16 & 0.14 \\
\hline 46 & $x, y-\operatorname{diMeC}_{30}$ & -0.37 & 0.16 & -0.13 & -0.70 & -0.22 & 0.06 \\
\hline 47 & $C_{31: 1}$ & -0.87 & -0.06 & 0.11 & 0.11 & 0.16 & -0.17 \\
\hline 48 & $\mathrm{x}_{2}-\mathrm{MeC}_{30}$ & 0.13 & 0.78 & -0.15 & 0.42 & -0.01 & 0.06 \\
\hline 49 & $n-C_{31}$ & -0.77 & -0.44 & -0.14 & -0.08 & -0.22 & -0.11 \\
\hline 50 & $\begin{array}{l}11-, 13-, 15- \\
\mathrm{MeC}_{31}\end{array}$ & -0.86 & 0.16 & 0.25 & -0.16 & 0.09 & -0.14 \\
\hline 51 & $\begin{array}{l}\text { 11,17-, 13,17-, } \\
\text { 15,19-diMeC }\end{array}$ & -0.87 & 0.18 & 0.15 & -0.26 & 0.13 & -0.03 \\
\hline & $\begin{array}{l}\text { of variance } \\
\text { ined }\end{array}$ & 49.7 & 13.2 & 8.9 & 5.8 & 4.6 & 2.3 \\
\hline
\end{tabular}


Table S3. Classification matrix showing the correct classification of queen-laid (Q-laid) and worker-laid (W-laid) eggs in Vespula vulgaris based on the cuticular hydrocarbons on the egg surface.

\begin{tabular}{lrrr}
\hline & Correct (\%) & Q-laid eggs & W-laid eggs \\
Q-laid eggs & 84.1 & 37 & 7 \\
W- laid eggs & 94.9 & 2 & 37 \\
Total & 89.2 & 39 & 44 \\
\hline
\end{tabular}


Table S4. Classification matrix showing the correct classification of reproductive queens (Q), spring-collected queens (SQ), virgin queens (VQ), and workers with fully-developed (FD), partially developed (PD), and undeveloped ovaries (UND) in Vespula vulgaris based on their cuticular hydrocarbon profiles.

\begin{tabular}{|c|c|c|c|c|c|c|c|}
\hline & Correct (\%) & $\mathrm{Q}$ & SQ & VQ & PD & UND & FD \\
\hline \multicolumn{8}{|c|}{ a) including workers with partially developed ovaries } \\
\hline $\mathrm{Q}$ & 100.0 & 13 & 0 & 0 & 0 & 0 & 0 \\
\hline SQ & 100.0 & 0 & 7 & 0 & 0 & 0 & 0 \\
\hline VQ & 100.0 & 0 & 0 & 17 & 0 & 0 & 0 \\
\hline $\mathrm{PD}$ & 37.5 & 0 & 0 & 0 & 3 & 0 & 5 \\
\hline UND & 71.4 & 0 & 0 & 0 & 0 & 35 & 14 \\
\hline FD & 84.1 & 0 & 0 & 0 & 1 & 6 & 37 \\
\hline Total & 81.2 & 13 & 7 & 17 & 4 & 41 & 56 \\
\hline \multicolumn{8}{|c|}{ b) excluding workers with partially developed ovaries } \\
\hline Q & 100.0 & 13 & 0 & 0 & & 0 & 0 \\
\hline SQ & 100.0 & 0 & 7 & 0 & & 0 & 0 \\
\hline VQ & 100.0 & 0 & 0 & 17 & & 0 & 0 \\
\hline UND & 71.4 & 0 & 0 & 0 & & 35 & 14 \\
\hline FD & 84.1 & 0 & 0 & 0 & & 7 & 37 \\
\hline Total & 83.8 & 13 & 7 & 17 & & 42 & 51 \\
\hline
\end{tabular}


Table S5. Classification matrix showing the correct classification of workers to their colony of origin in Vespula vulgaris based on their cuticular hydrocarbon profiles.

\begin{tabular}{lcccccc}
\hline & Correct (\%) & Colony A & Colony B & Colony C & Colony D & Colony E \\
Colony A & 47.4 & 9 & 6 & 2 & 1 & 1 \\
Colony B & 55.0 & 4 & 11 & 2 & 1 & 2 \\
Colony C & 85.0 & 2 & 1 & 17 & 0 & 0 \\
Colony D & 80.0 & 0 & 0 & 0 & 16 & 4 \\
Colony E & 54.5 & 4 & 2 & 0 & 4 & 12 \\
Total & 64.4 & 19 & 20 & 21 & 22 & 19 \\
\hline
\end{tabular}


Table S6. Factor loadings of the hydrocarbon compounds on the seven PCs with an eigenvalue greater than 1. For information on the value of $\mathrm{x}$, see Table S1.

\begin{tabular}{|c|c|c|c|c|c|c|c|c|}
\hline $\begin{array}{l}\mathrm{Pe} \\
\text { ak } \\
\text { no. }\end{array}$ & Component & PC 1 & PC 2 & PC 3 & PC 4 & PC 5 & ·PC 6 & PC 7 \\
\hline 1 & $n-C_{23}$ & 0.14 & 0.54 & 0.45 & 0.30 & -0.21 & -0.37 & -0.32 \\
\hline 2 & $9-, 11-\mathrm{MeC}_{23}$ & 0.27 & 0.88 & 0.03 & 0.08 & -0.27 & -0.24 & 0.07 \\
\hline 3 & $7-\mathrm{MeC}_{23}$ & 0.21 & 0.86 & -0.06 & -0.17 & -0.36 & -0.09 & 0.13 \\
\hline 4 & $5-\mathrm{MeC}_{23}$ & 0.21 & 0.92 & 0.08 & 0.10 & -0.26 & -0.03 & 0.07 \\
\hline 5 & $3-\mathrm{MeC}_{23}$ & 0.06 & 0.93 & 0.02 & 0.08 & -0.16 & -0.11 & -0.14 \\
\hline 6 & $5, x-\operatorname{diMeC}_{23}$ & 0.18 & 0.91 & -0.02 & 0.27 & 0.10 & 0.01 & 0.05 \\
\hline 7 & $n-C_{24}$ & 0.25 & 0.55 & 0.71 & 0.03 & -0.03 & -0.26 & 0.07 \\
\hline 8 & $3, x-$ diMeC $_{23}$ & 0.14 & 0.95 & -0.03 & 0.13 & 0.09 & -0.02 & 0.05 \\
\hline 9 & $\begin{array}{l}10-, 12-, 14- \\
\mathrm{MeC}_{24}\end{array}$ & 0.01 & 0.98 & -0.04 & 0.08 & -0.07 & -0.05 & 0.11 \\
\hline 10 & $6-\mathrm{MeC}_{24}$ & 0.09 & 0.82 & -0.18 & -0.17 & -0.08 & 0.19 & 0.35 \\
\hline 11 & $4-\mathrm{MeC}_{24}$ & -0.03 & 0.85 & -0.06 & 0.04 & 0.14 & 0.27 & 0.27 \\
\hline 12 & $\mathrm{C}_{25: 1}$ (+ isomer) & -0.15 & 0.81 & -0.20 & 0.31 & -0.21 & 0.00 & 0.23 \\
\hline 13 & $4, \mathrm{x}$-diMeC 24 & -0.10 & 0.91 & 0.01 & 0.19 & 0.28 & 0.12 & 0.00 \\
\hline 14 & $n-C_{25}$ & -0.06 & 0.06 & 0.90 & 0.32 & 0.02 & -0.20 & -0.02 \\
\hline 15 & $\begin{array}{l}\text { 11-, 13-, 15- } \\
\mathrm{MeC}_{25}\end{array}$ & -0.46 & 0.79 & 0.13 & 0.16 & -0.07 & -0.07 & -0.10 \\
\hline 16 & $7-\mathrm{MeC}_{25}$ & -0.47 & 0.76 & 0.06 & -0.16 & -0.22 & 0.22 & 0.12 \\
\hline 17 & $5-\mathrm{MeC}_{25}$ & -0.66 & 0.59 & 0.28 & -0.08 & -0.15 & 0.17 & -0.06 \\
\hline 18 & $3-\mathrm{MeC}_{25}$ & -0.49 & 0.59 & 0.48 & 0.10 & 0.24 & 0.16 & -0.10 \\
\hline 19 & $5, x$-diMeC 25 & -0.37 & 0.83 & 0.03 & 0.21 & 0.29 & 0.08 & -0.13 \\
\hline 20 & $n-C_{26}$ & -0.19 & -0.14 & 0.93 & -0.04 & 0.06 & -0.04 & 0.19 \\
\hline 21 & $3, x-$ diMeC $_{25}$ & -0.35 & 0.84 & 0.10 & 0.09 & 0.33 & 0.12 & -0.08 \\
\hline 22 & $\begin{array}{l}10-, 12-, 14- \\
\mathrm{MeC}_{26}\end{array}$ & -0.83 & 0.46 & -0.07 & -0.09 & -0.02 & -0.02 & -0.07 \\
\hline 23 & $4-\mathrm{MeC}_{26}$ & -0.64 & 0.16 & 0.23 & -0.52 & 0.13 & 0.13 & 0.35 \\
\hline 24 & $\mathrm{C}_{27: 1}$ (+isomer) & -0.81 & 0.02 & -0.22 & 0.38 & -0.19 & 0.08 & 0.07 \\
\hline 25 & $4, x-\operatorname{diMeC}_{26}$ & -0.76 & 0.53 & -0.02 & -0.21 & 0.19 & 0.11 & -0.05 \\
\hline 26 & $n-\mathrm{C}_{27}$ & -0.44 & -0.52 & 0.62 & 0.32 & -0.05 & 0.01 & 0.02 \\
\hline 27 & $11-, 13-\mathrm{MeC}_{27}$ & -0.91 & -0.04 & 0.02 & -0.17 & -0.27 & -0.09 & -0.17 \\
\hline 28 & $7-\mathrm{MeC}_{27}$ & -0.89 & -0.07 & 0.00 & -0.17 & -0.25 & 0.17 & 0.04 \\
\hline 29 & $5-\mathrm{MeC}_{27}$ & -0.71 & -0.30 & 0.03 & -0.51 & -0.27 & -0.04 & 0.06 \\
\hline 30 & $11,15-$ diMeC $_{27}$ & -0.61 & 0.13 & -0.02 & -0.25 & 0.23 & -0.54 & 0.25 \\
\hline 31 & $3-\mathrm{MeC}_{27}$ & -0.69 & -0.27 & 0.55 & -0.27 & 0.07 & 0.15 & 0.08 \\
\hline 32 & $5, x-$ diMeC $_{27}$ & -0.80 & 0.25 & -0.11 & -0.43 & 0.05 & -0.09 & -0.18 \\
\hline 33 & $n-C_{28}$ & -0.47 & -0.58 & 0.55 & 0.15 & -0.02 & 0.10 & 0.13 \\
\hline 34 & $3, x-$ diMeC $_{27}$ & -0.85 & 0.33 & 0.03 & -0.32 & 0.11 & 0.05 & -0.17 \\
\hline 35 & $\begin{array}{l}10-, 12-, 14- \\
16-\mathrm{MeC}_{28}\end{array}$ & -0.91 & -0.06 & -0.26 & -0.18 & -0.07 & -0.07 & 0.01 \\
\hline 36 & $4-\mathrm{MeC}_{28}$ & -0.35 & -0.14 & -0.33 & 0.20 & 0.17 & -0.42 & 0.52 \\
\hline 37 & $\mathrm{C}_{29: 1}$ & -0.72 & -0.18 & -0.10 & 0.57 & -0.20 & -0.01 & -0.14 \\
\hline
\end{tabular}




\begin{tabular}{|c|c|c|c|c|c|c|c|c|}
\hline 38 & $4, \mathrm{x}-\mathrm{diMeC}_{28}$ & -0.83 & 0.02 & -0.26 & -0.40 & 0.02 & -0.01 & -0.06 \\
\hline 39 & $n-C_{29}$ & -0.54 & -0.53 & 0.28 & 0.54 & -0.02 & 0.06 & 0.00 \\
\hline 40 & $\begin{array}{l}11-, 1_{-}, 15- \\
\mathrm{MeC}_{29}\end{array}$ & -0.89 & -0.24 & -0.08 & 0.15 & -0.28 & -0.09 & -0.12 \\
\hline 41 & $7-\mathrm{MeC}_{29}$ & -0.74 & -0.26 & -0.25 & 0.03 & 0.06 & -0.44 & 0.24 \\
\hline 42 & $3-\mathrm{MeC}_{29}$ & -0.64 & -0.58 & 0.34 & 0.10 & 0.04 & 0.12 & 0.14 \\
\hline 43 & 5,9-diMeC 29 & -0.90 & 0.07 & -0.15 & -0.24 & 0.01 & -0.08 & -0.22 \\
\hline 44 & $n-C_{30}$ & -0.97 & -0.07 & -0.10 & -0.03 & 0.05 & 0.05 & -0.11 \\
\hline 45 & $\mathrm{x}_{1}-\mathrm{MeC}_{30}$ & -0.12 & 0.24 & -0.36 & 0.68 & -0.08 & 0.02 & -0.13 \\
\hline 46 & $\mathrm{x}, \mathrm{y}-\mathrm{diMeC}_{30}$ & 0.86 & -0.43 & -0.11 & -0.22 & 0.01 & 0.04 & -0.07 \\
\hline 47 & $\mathrm{C}_{31: 1}$ & -0.59 & -0.08 & -0.33 & 0.49 & 0.17 & 0.27 & 0.02 \\
\hline 48 & $\mathrm{x}_{2}-\mathrm{MeC}_{30}$ & -0.36 & 0.19 & -0.17 & 0.06 & 0.60 & -0.31 & -0.19 \\
\hline 49 & $n-C_{31}$ & -0.34 & -0.50 & -0.03 & 0.54 & 0.00 & 0.19 & 0.31 \\
\hline 50 & $\begin{array}{l}11-, 1^{-,}, 15- \\
\mathrm{MeC}_{31}\end{array}$ & -0.75 & -0.38 & -0.19 & 0.34 & -0.21 & -0.09 & 0.08 \\
\hline 51 & $\begin{array}{l}\text { 11,17-, 13,17-, } \\
15,19-\text { diMeC }_{31}\end{array}$ & -0.57 & -0.26 & -0.30 & 0.59 & 0.17 & -0.06 & 0.00 \\
\hline & $\begin{array}{l}\text { of variance } \\
\text { ined }\end{array}$ & 33.4 & 30.9 & 9.6 & 8.6 & 3.6 & 3.2 & 2.8 \\
\hline
\end{tabular}


Table S7. Classification matrix showing the correct classification of workers with undeveloped ovaries to their colony of origin in Vespula vulgaris based on their cuticular hydrocarbon profiles.

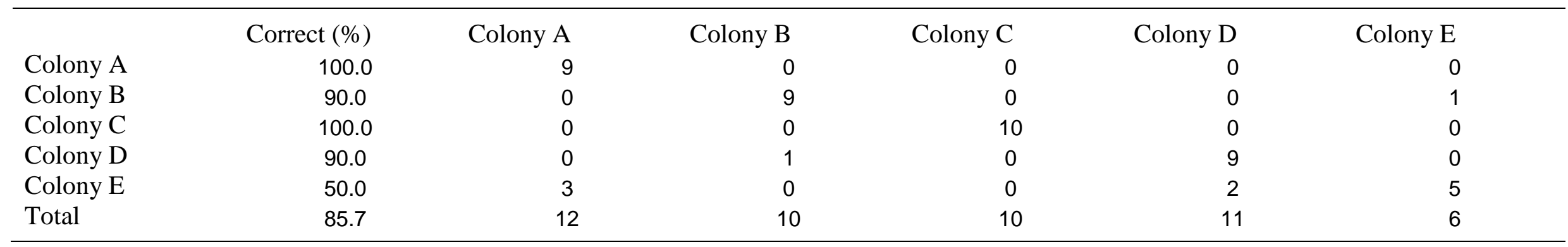

